\title{
5
}

\section{The Desires of Postcolonial Orientalism: Chinese Utopias of Kristeva, Barthes, and Tel quel}

\begin{abstract}
On comprend donc comment . . . la révolution culturelle prolétarienne chinoise, plus grand événement historique de notre époque, dérange le calcul révisionniste et qu'il fera tout pour la falsifier. Eh bien, nous, nous ferons tout pour l'éclairer, l'analyser et la soutenir.

[We understand how, then . . . the Chinese Cultural Proletarian Revolution, the greatest historical event of our epoch, so disturbs the revisionist reasoning that they will do everything to falsify it. And so, for our part, we will do everything to illuminate it, to analyze it, and to support it.]
\end{abstract}

Tel quel (1971)

The discourse of orientalism is never independent of the contiguous discourses that figure otherness. Discourses operate in conflict, and each discourse is actively bound to other discourses which may reiterate, contradict, and criticize its ruling figurations. The notion of woman as Other, for example, takes shape in a field defined, on the one hand, by scientific, psychoanalytic, and literary representations of "woman" and, on the other, by feminist critiques of these representations. Likewise, we saw in the last chapter that Indianness as difference forms a multivalent hinge between the British colonialist discourse, which excluded Indians, and the Indian articulations of identity that criticize that discourse. It has been my argument throughout that constructions of difference are multivalent signifiers, and are 
produced by the active engagement of a plurality of discourses at different moments. Orientalism must be understood as but one discourse in this complex intersection.

In this chapter my object of study is again literary criticism, as I consider a more recent orientalism, the figuration of the Chinese Cultural Revolution and the People's Republic of China by French intellectuals during the early 1970s in Julia Kristeva's Des chinoises (1974), Roland Barthes's Alors la Chine? (1975), and the avant-garde theoretical journal Tel quel (1968-1974). An assortment of discourses invents and circulates the multivalent signifier "China" in these three examples; although each representation of China arises from the social circumstances of Paris in the 1960s and 1970s, each is figured differently, answering differently urgent quests emerging from the social circumstances and discursive formations of that period. Kristeva represents China as a culture descending from a pre-oedipal matriarchal heritage; her figuration of Chinese otherness is part of a strategy to subvert western ideology by positing a feminine, maternal realm outside its patriarchal system. Kristeva's China expresses a confluence of the discourses of feminist theory, psychoanalysis, and semiotics, as well as orientalism. Barthes's China-which he constitutes as a poetic site outside western signification, a pre-Symbolic space also coded as maternal-marks another intersection of these same semiotic, psychoanalytic, and orientalist discourses. Finally, the embrace of Maoism by the theorists of the journal Tel quel in 1971, in which communist China is figured as the revolutionary Other of western society and western Marxist theory, occurs at the nexus of orientalism and the discourses of the French Left after 1968.

Within the context of my discussion of earlier orientalisms, one can see that these expressions of postcolonial French relations to the Orient are at once both strikingly different from the earlier French colonial orientalism and disturbingly reminiscent of its postures and rhetorics. The main manner in which the China of Kristeva, Barthes, and Tel quel differed from the orientalist texts produced during the earlier periods was that their various deployments of the orientalist trope were meant to represent a break with colonialist ideology; Kristeva, Barthes, and Tel quel were openly antagonistic toward the ideologies of national homogeneity, centralized state power, and the French subordination of North Africa and Indochina. Indeed, the French construction of 
China in the 1970s was central to a counterideological politics; China was constructed as an object of desire within particular veins of the counterideological discourses of feminism, psychoanalysis, and French Maoism, whose project was the criticism of French culture and whose key theoretical strategies depended on an assertion not of national homogeneity but of difference and the self-determination of a variety of peoples. In this sense the postcolonial discourse about China appropriated certain orientalist tropes in order to criticize the state apparatus of which the earlier colonialist orientalism was a product. Opposed to, yet in a dialogic relation with, traditional orientalism, this postcolonial form of orientalism departed from, yet was determined by, the discursive conditions of the previous orientalisms. Although Kristeva's, Barthes's, and Tel quel's representations of China served as critiques of the nationalist ideologies supported by earlier orientalisms, their figurations of the Orient utilized some of the very same terms, postures, and rhetorics employed in the earlier texts.

Before the pieces about China, both Barthes and Kristeva were known for their significant works in semiological theory, Barthes's Eléments de sémiologie (1965) and Kristeva's Révolution du langage poétique (1974). Both theorists wrote their pieces on China at a moment in theoretical debates when the binary oppositions upheld by structuralist analysis - self and Other, male and female, culture and naturewere being targeted by theories of language, psychoanalysis, and anthropology as reductive logics to be revised and superseded. It is in this context that Kristeva and Barthes constituted China as an irreducibly different Other outside western signification and the coupling of signifier and signified. Yet the desires shaping their texts were inscribed by the very terms they wished to escape; for the wish to exceed western binary systems is a desire that is itself structured by the opposition between the location of one's writing - within structureand the place of the transcendent Other-beyond structure.

The reassertion of the oppositions that Barthes and Kristeva sought to escape in their writings on China can be most clearly traced, interestingly enough, in the way in which their texts ultimately privilege psychoanalysis, a paradigm that stubbornly returns to the binarism of male and female. Invoking French debates on feminism and psychoanalysis during the 1970s, both writers coded China as feminine or maternal, in contradistinction to the paternal order of French society. 
Kristeva's Des chinoises (1974) invokes the matriarch of pre-Confucian China as a means of naming and projecting a figure that occupies a space beyond the structured and determined sexuality of western Europe. She associates the period of matriarchy and matrilineality in China with the "phase pré-oedipienne," a reconstituted period in which the child is intensely allied with the mother before its entry into the Symbolic order of socialization and language. In this sense, Des chinoises is a text that embodies several desires: a theoretical desire to locate a position outside French structuralism and psychoanalysis from which these paradigms may be criticized; a feminist desire to discover and praise a figure of absolute feminine power and to locate a matriarchal society in which this power is effected; and finally a desire, inherited from the discourse of orientalism, to find in the history of the Orient the opposite of the Occident, to find there all that is absent from and beyond the West.

Barthes's Alors la Chine? (1975) also juxtaposes China-in cultural, semiotic, and psychoanalytic terms - to the overstructured, signifying West. Like Kristeva, Barthes constitutes China as a feminine, maternal space that disrupts the "phallocentric" occidental social system. By associating China with the maternal, Barthes suggests that the Orient is opposed to the representational Symbolic system of the West; for Barthes, China opens up the possibility of a preverbal Imaginary space, before "castration," socialization, and the intervention of the Father. In the sense that China is conflated with the significance of the maternal in Barthes's critical project, orientalism becomes a means of figuring this critical poetics of escape, a topos through which one writes oneself outside western ideology.

Kristeva's and Barthes's interests in the People's Republic of China were shared by other intellectuals and critics who were their contemporaries. At the same time that Des chinoises and Alors la Chine? were written, the editorial committee at the journal Tel quel (which included Kristeva, as well as Philippe Sollers, Jean-Louis Baudry, Marcelin Pleynet, and others) had become ardent followers of the Chinese Cultural Revolution. After 1968 these critics and intellectuals, who judged the promising yet ultimately suppressed May revolts in France a failed revolution, turned to the Cultural Revolution as an alternative example of revolutionary theory and practice. These intellectuals adopted "Maoism" and defined it as a more radical critique of society, one that 
took its theoretical inspiration from a source outside western Marxism. In $1971 \mathrm{Tel}$ quel issued a "Déclaration" of its embrace of "la pensée maotsétoung." In this document, "la pensée maotsétoung" was the sign for French communism's Other, a manner of signifying a more revolutionary practice, whose very political and geographic distance from the West rendered it more powerful because it could not be subsumed by western social systems or explanations. Although the China constituted by Tel quel as the political Other of western Marxist theory and practice was inflected differently from Kristeva's or Barthes's, the three representations resembled one another to the degree that they constituted China as a utopian antithesis to French society and culture.

The fascination with this China in the works of Kristeva and Barthes and in Tel quel expressed the dilemmas of a particular historical context and a specific set of issues and controversies: these invocations of China were written within theoretical, and political debates particular to Paris in the early 1970 - feminist, psychoanalytic, and French Maoist. Most important, they were also written following the student revolts and workers' strikes of May 1968, which demanded radical changes in the authoritarian structures of the university, the factory, and in society at large. In the aftermath of 1968, when the revolts had been suppressed and Gaullist power restored, leftist intellectuals struggled to explain what had happened, what might have happened, and what remained to be done. In this sense all three figurations of China-as feminist, psychoanalytic, and leftist utopias-were indirect responses to the events of 1968; they attempted to continue the project of cultural politics begun in 1968, but in choosing to constitute as utopian a revolutionary experience outside Europe, they betrayed their disillusionment at the suppression of the French revolts.

\section{Des Chinoises: Orientalism, Psychoanalysis, and Feminine Writing}

Des chinoises was written in the context of both the western Continental feminist debates of the early 1970s and the structuralist and psychoanalytic theoretical debates of the same period; in this sense writing about "la chinoise" was an occasion for Kristeva to critique the 
lack of psychoanalytic sophistication in the French and North American women's movements, as well as a means of providing a feminist critique of the Freudian and Lacanian paradigms of sexual difference. ${ }^{1}$ Des chinoises invokes the powerful figure of an ancient Chinese matriarch as the disrupting exception to western patriarchy and psychoanalysis, and the People's Republic of China is praised as a political antithesis to contemporary France. In both senses the examples of China and Chinese women are cited only in terms of western debates, are invented as solutions to western political and theoretical problems.

A hierarchical opposition of occidental and oriental is stated in the formal divisions themselves which frame and structure the entire text: a first section, "De ce côté-ci," (From this side), and a second section titled "Femmes de Chine" (Chinese women). "De ce côté-ci" contains five chapters describing the oppression of women in the western traditions of sexual differentiation and definition: first, the patrilinear monotheistic tradition exemplified by the Old Testament separating men and women into two races and subjugating "la femme" to the privileged identity of "l'Homme"; and second, the Freudian and Lacanian psychoanalytic explanation of sexual difference. Subsequently, in the section "Femmes de Chine," this bipartite narrative about

1The Mouvement de libération des femmes (MLF), very active after May 1968, was, in 1974, discussing issues of psychoanalysis, socialism, Marxism, Maoism, and the bearing of these systems of thought and social analysis on the question of women's liberation. By 1977 the MLF had split into at least two factions: those who allied themselves with "psychanalyse et politique" and those who allied themselves with "questions féministes." The "psychanalyse et politique" group, with which Kristeva was associated, concerned itself with women's psycholinguistic position, and explored psychoanalysis as an emancipatory theory of sexual difference. The supporters of "questions féministes," coming out of Simone de Beauvoir's existential feminism, were more concerned with the material conditions of women as a subordinated class. The concerns of Christine Delphy, who, along with Beauvoir, was one of the founding members of the journal Questions féministes, may be considered to have much more in common with the Marxist feminism practiced in the United States. For other discussions of the recent history of French feminism, see Elaine Marks and Isabelle De Courtivron, eds., New French Feminisms (Amherst: University of Massachusetts Press, 1980); Ann Rosalind Jones, "Writing the Body: Toward an Understanding of L'Écriture Féminine," Feminist Studies 7, no. 2 (Summer 1981): 247-63; and Toril Moi, Sexual/Textual Politics: Feminist Literary Theory (London: Methuen, 1985). See also the special issues of the journals Signs 7, no. 1 (Autumn 1981); Feminist Studies 7, no. 2 (Summer 1981); and Yale French Studies 62 (1981), each addressing the question of French and Anglo-American feminism. In particular, see Gayatri Spivak's "French Feminism in an International Frame," in In Other Worlds (London: Routledge, 1988), first published in YFS 62 (1981): 154-84, for both its instructive discussion of Des chinoises and its equally relevant critique of French feminism. 
women in western history is posed against a bipartite narrative about China; with the parallelism of the two cleft narrative reconstructions of Occident and Orient, Kristeva argues that the ancient matriarchal origins of China contrast with the patrilinear monotheism of the Judeo-Christian biblical tradition, whereas the long Confucian period of Chinese history resembles that of the western psychoanalytic repression of femininity.

In chapter 2 of part 1, "La guerre des sexes," Kristeva discusses western religious and legal discourse; man is genealogically linked to the one God, she argues, whereas woman is excluded from this genealogy. ${ }^{2}$ The woman qualifies as human subject only in her relation as "épouse," and in her contractual agreement to bear man's children. Within these traditions, man possesses social subjectivity, access to language, and legal and historical presence; woman, Kristeva argues, is constituted by the tradition as the Other, who is mute, powerless, outlawed, ahistorical, and absent. Kristeva's analysis of the Old Testament tradition is a structuralist one, which relies on binary systems of classification (presence and absence, speeched and speechless, man and woman, and so on). In a sense, her interpretation foregrounds the inherent limitations of structuralism as a method of criticism for articulating a feminist project: the fixed nature of the paradigm, and the extent to which structuralism posits and assumes the binary complementarity of the dyad man/woman without providing the tools for an adequate critique of the production of this binary logic. In effect, the structuralist method utilized here constitutes the binary oppositions it ostensibly identifies. ${ }^{3}$ In order to find a critical methodology less static

\footnotetext{
2Kristeva observes: "Coupée de l'homme, faite dans cela même qui lui manque, la femme biblique sera épouse, fille ou soeur. . . . Sa fonction est d'assurer la procréation . . . elle n'a pas de rapport direct: Dieu ne parle généralement qu'à l'homme" (Cut from man, made from that which he lacks, the biblical woman will be wife, daughter or sister. . . . Her function is to insure procreation ... she has no direct relationship: God speaks only to man; p. 21).

${ }^{3}$ For example, structural anthropology assumed that the cultural order was founded on the division of society into two sexes: men, who were the social and cultural actors, and women, who were the objects of exchange among men. In Claude Lévi-Strauss's "Language and the Analysis of Social Laws," in Structural Anthropology (New York: Basic Books, 1963), the observation that women serve as objects of exchange in culture is offered as "proof" that women are the signifiers of men's roles as producers of culture. The structural paradigm is essentially a description-as opposed to a historical, hermeneutical, or dynamic explanation-that presumes sexual difference as a given binary relationship.
} 
than structuralist description, "De ce côté-ci" then turns to psychoanalysis as a method that attempts to account for the formation of the subject in language and culture. Yet whereas the theoretical limitations of psychoanalysis are different from the problems of binary reductionism inherent in structuralism, Kristeva's particular use of psychoanalysis in Des chinoises implicates its arguments about sexual difference in another set of determined relations.

Psychoanalysis presumes that sexuality is at the center of a subject's identity within family, language, and social arrangements; because the issue of sexuality is central to so many feminist theorists, the attraction to psychoanalysis among feminists is understandable. ${ }^{4}$ But the ultimate psychoanalytic revelation that gendered subjectivity is determined by the presence or lack of a penis (in the case of Freud) or the phallus (in the case of Lacan) insistently frustrates the feminist project, to the extent that psychoanalytic explanation of gender tends to rely on an arbitrary assignment of a masculine mark to describe a difference that needs also to be explained by other, more varied methods of analysis and explanation, such as sociology and the construction of sexual difference, economics and the relationship of class and gender, or social history and the production of race and gender. ${ }^{5}$ In Des chinoises, Kristeva's critique of psychoanalysis consists in revalorizing Freud's formulation of a pre-oedipal phase by imputing to it certain characteristics extrapolated from Lacan's notion of the Imaginary. ${ }^{6}$ In

${ }^{4} \mathrm{As}$ this chapter implies, Freud and Lacan were prominent influences in the formation of French feminist theories, particularly on the work of Luce Irigaray, Hélène Cixous, Claudine Hermann, and Xavière Gauthier. Feminists in the United States, on the contrary, have been more critical of psychoanalytic theories (unlike English feminists; see, for example, Juliet Mitchell's Psychoanalysis and Feminism [New York: Viking, 1974]). In the years since the mid-1970s, however, more American feminists have written about the question of sexual difference from psychoanalytic standpoints; see, for example, Jane Gallop, The Daughter's Seduction (Ithaca: Cornell University Press, 1982).

${ }^{5}$ Some of these other methods of explication are represented in the works of Rosalind Pechesky (1981) on reproductive rights; Catharine MacKinnon (1987) on the position of women in legal discourse; Nancy Chodorow (1978) on the role of mothering in the social construction of gender; bell hooks (1981) on black women and feminism; and Donna Haraway (1985) on science, technology, and socialist feminism.

"Although it was Freud who originally described the "pre-Oedipus period" in the lecture "Femininity," in New Introductory Lectures on Psychoanalysis, trans. James Strachey (New York: Norton, 1964), as the period of preinfantile sexual attachment of the daughter to her mother before she discovers that she and her mother are "castrated," Freud's references to the pre-oedipal stage are associated with an interest in describing how female "regressions" into the "prehistory" of the bond between mother and infant affect 
chapter 3 of part 1, "Vierge du verbe," Kristeva expands Freud's notion of the pre-oedipal stage-a period anterior to the legendary castration, before the child acquires speech and enters into social relations-by stressing the importance of rediscovering the powerful sexuality of the mother. Following Freud and Lacan, Kristeva adopts the pre-oedipal as a "prehistory" to oedipalization, but in contradistinction to Freud and Lacan, for whom the overwhelming significance lies in the process of oedipalization, Kristeva inflects the "regressions" toward pre-oedipal eroticism for the mother with a positive value.

[Il y a] deux processus d'ordre psychanalytique, l'un relatif au rôle de la mère, l'autre au fonctionnement du langage.

Le premier consiste à lever le refoulement sur le fait que la mère est autre, n'a pas de pénis, mais jouit et enfante. De lever le refoulement jusqu'au préconscient seulement : tout juste pour imaginer qu'elle enfante, mais en censurant le fait qu'elle a joui dans un coït, donc qu'il y a eu la "scène primitive." Une fois de plus, le vagin et la jouissance de la mère sont méconnus et immédiatement remplacés par ce qui place la mère du côté de la communauté socio-symbolique : l'enfantement, la filiation au nom du père. Cette opération de fausse reconnaissance-de méconnaissance-de la jouissance maternelle s'accomplit grâce à un processus dont Ernest Jones a le premier entendu la source. ${ }^{7}$

[There are two processes in psychoanalysis, one pertaining to the role of the mother, the other as a result of language.

The first one consists in lifting the repression of the fact that the mother is other, has no penis, but enjoys pleasure and brings forth children. To lift the repression only to the preconscious, just to imagine that she is procreative, but censoring the fact that she has had sexual pleasure in intercourse, in which there was a "primal scene." Further, the mother's vagina and pleasure are misrecognized and immediately replaced by the circumstances which situate the mother on the side of the socio-symbolic community: childbirth, the relationship to the name of the father. This operation of false recognition - of misrecognition - of maternal pleasure is realized according to a process of which Ernest Jones was the first to understand the source.]

the development of femininity; see, for example, his theories that jealous paranoia and female homosexuality are conditions "which went back to a fixation in the pre-Oedipus stage" (p. 115). Indeed, Freud suggests in this lecture that the claims of women patients that they had been seduced by their father were "hysterical symptoms," but that the fantasy of seduction by the mother "touches the ground of reality, for it was really the mother who by her activities over the child's bodily hygiene inevitably stimulated, and perhaps even roused for the first time, pleasurable sensations in her genitals" (p. 106).

${ }^{7}$ Kristeva, Des chinoises, p. 30. 
This passage refers to the premises of castration and the repression of the knowledge of women as both generative and sexual to explain, on the one hand, the Symbolic appropriation of the woman's body and sexual pleasures, and, on the other hand, the exclusion of women from a masculine model of socialization and subjectivity. Kristeva asserts that the multiple and nonexclusive sexual pleasures of the mother"le vagin et la jouissance" (emphasis added)—are misrecognized, or repressed, and that psychoanalysis accounts for this misrecognition as necessary for the preservation of a male order. The implicit reference to castration is significant, for it is through the drama of castration as the repression of the child's vision of the mother's sexuality that psychoanalysis explains the formation of masculine identity. Kristeva argues that it is the child's belief in castration that represses a knowledge of the mother-as sexual, fertile, and vaginal-and in this belief that the denial and appropriation of women's sexual pleasure, or "jouissance," takes place.

Kristeva's refiguration of the pre-oedipal phase draws somewhat upon the Lacanian notion of the Imaginary-a hypothetical, specular, preverbal topos reconstructed from the standpoint of the Symbolic. Lacan's definition of the Imaginary includes a "mirror stage," a hypothetical phase in which the preverbal child identifies with a specular reflection (or misidentifies, in that it is through identification with images that the subject misrecognizes itself, and constructs the alienated self, which Lacan calls the ego or moi). It is termed the Imaginary, because for Lacan the supposition of a period of narcissistic identification and fullness is a mythical stage; it exists only as a recapitulation of an "imaginary" pre-Symbolic state from the standpoint of the subject who is always already within language, the paternal order, social hierarchy, and law. Lacan discusses oedipalization, therefore, not as Freud's scene in which the child fears castration and identifies with the father's masculinity, but rather as a metaphor for the accession of the subject to the socialized sphere of Symbolic relations. The Lacanian Oedipal phenomenon consists of this initiation into the Symbolic, emblematized by the naming/castration of the subject in language, the receipt of the nom and the non of the father. With the entry of the named subject into language and the social order, the unnamed, repressed desires of the subject are driven underground. This division of the subject in language is crucial to the functions of desire and symbol- 
ization, for it is in the Symbolic relations of language that the subject attempts to reconstruct the identities and equivalences of the Imaginary. In rewriting the Lacanian notion of the Imaginary as a female pre-oedipal phase, Kristeva privileges the infant's identification with the mother rather than the specular identification stressed by Lacan: "L'Enfant est lié au corps de la mère sans que celui-ci soit encore un 'objet-en-face,' mais jouant, avec le corps enfantin lui-même, comme un continuum socio-naturel" (The child is bound to the mother's body without that body being, as yet, 'other'; rather, her body 'pleasures' with the child's body itself, in a kind of natural/social continuum; p. 32). Thus, Kristeva expands the notion of the pre-oedipal/Imaginary in opposition to castration, oedipalization, and the Lacanian Symbolic; the formulation of the pre-oedipal represents an attempt to locate a space outside the phallic-dominated Symbolic for a maternal, feminine-dominated phase of psychosexual development. ${ }^{8}$

Kristeva's revalorization of the pre-oedipal as an absolute state of otherness with regard to the paternalistic Symbolic and its systems of signification is figured in an idealized Other-the Mother-located outside the hierarchical, oedipalized overdetermination of western psychoanalysis. But Kristeva does more than idealize this Mother; she "orientalizes" her. In the book's second section, "Femmes de Chine," Kristeva constitutes an ancient matrilinear-matrilocal society as the historical analogue to the female-dominated pre-oedipal topos, conflating the matriarch of pre-Confucian China with the mother in pre-

${ }^{8}$ Kristeva adopts, yet revalorizes, Freud's notion of the pre-oedipal phase. For Freud, children discover the difference between the father and mother when they observe the father has a penis; assuming that the mother's penis has been cut off, they identify with the father, refusing bonds with the mother, owing to the imagined threat of castration. According to Freud, the imagined castration is all the more important to the male child, for the successful repression of his desire for his mother, through the fear of castration, allows him to adjust to the conditions of adult society, to become socialized as a man. Kristeva suggests that the oedipal repression must be lifted and the mother rediscovered as the child's object of desire and union.

The construction of the ego in the mirror stage, as well as the relationship between the Imaginary and the Symbolic realms, is developed in Jacques Lacan's essay "The Mirror Stage as Formative Function of the I as Revealed in Psychoanalytic Experience," in Ecrits. The Symbolic, the oedipal phenomenon, and the naming and splitting of the subject are discussed in "The Agency of the Letter in the Unconscious or Reason since Freud," also in Ecrits. Useful exegeses of Lacan's work include Coward and Ellis 1977; Jameson 1977; Lemaire 1977; Wilden 1968; and Mitchell and Rose's preface to Lacan, Feminine Sexuality 1983. 
oedipal discourse. Both projects place the Mother at the center of their respective paradigms: as the primary figure in child development and gender acquisition, and as the origin of social and economic organization. Both efforts depend on the retrospective invention of a prehistorical moment, an idealized state outside society and history, created from a point located within social arrangements. In the argument that Chinese matriarchy is the antecedent of a twentieth-century revolutionary society, the generalizing narrative, undaunted by the large scope of its project, leaps quickly and simply across two thousand years of Chinese history to propose that, because of China's matriarchal heritage, the communist politics of the People's Republic hold powerful lessons for the French Left in the 1970s. Throughout Des chinoises a historical extravagance, which so easily establishes a correspondence between an ancient modality and a contemporary one, lacks an adequately complex appreciation of the heterogeneous and contradictory forces of history; despite an ostensible allegiance to Marxism, Kristeva finds no apparent difficulties in generalizing Chinese history in so undialectical a fashion.

Kristeva first evokes the mother-centered society of pre-Confucian China in chapter 1 of part 2, "La mère au centre," in a fantasy-description of matrilinear kinship and matrilocal systems of exchange in ancient China. She suggests that genealogy issued from mother to daughter, and that the family groups within each region were organized along maternal lines; that is, the son-in-law moved to the wife's mother's district. In addition, males and females had equal power in the social and political spheres of activity; this is symbolized, she claims, by symmetrically binomial names that include the name of the mother (also the name of the region) as well as the paternal family name. Kristeva employs conditional verb tenses to evoke this ancient system, calling attention to its hypothetical and fictive qualities: "Une certaine prépondérance des femmes pourrait pourtant être logiquement nécessaire à une époque archaïque et expliquerait une filiation matrilinéaire et matrilocale" (A certain preponderance of women would be however logically necessary in this period, and would explain a lineage both matrilinear and matrilocal; p. 51, emphasis added). Indeed, Kristeva candidly comments on the quality of invention, and of phantasm in her history of the woman-dominated Chinese society"hypothétique (utopique? fantasmatique?)" (p. 48)—and the fact that 
she selectively chooses this image of matrilinear-matrilocal society from particular, and few, western sinologists' texts. 'As with the embellishment of the pre-oedipal phase in the first section of Des Chinoises, in this second section the invented matrilinear-matrilocal society is likewise exploited for its quality of utopia and phantasm; as an Imaginary, and therefore untextualized, Other, the Chinese matriarchy offers the writer of "écriture féminine" a powerful topos with which to subvert the narratives of western patrilineality.

Kristeva also justifies the mother-centered theories of the pre-oedipal phase and the pre-Confucian matriarchy in an "analysis" of Chinese language. She argues that the independence of two linguistic systems - of tonal speech and of written ideogrammatic symbols-is particular to the Chinese language, and that the independent system of tonal speech is a preserved remnant of the matrilinear-matrilocal society, in which the mother and her bodily preverbal tones and rhythms were dominant. Earlier, Kristeva had characterized the preoedipal relationship of infant and mother as one of preverbal "echolalia": "La phase pré-oedipienne corresponde à des écholalies intenses, à des rythmes d'abord et à des intonations ensuite, avant que ne s'installe la structure phonologico-syntaxique de la phrase" (The pre-oedipal phase corresponds to an intense echolalia, first in rhythm and then in intonation, before the phonologico-syntactic structure is imposed on the sentence; p. 34). In this discussion of the relationship between written and spoken Chinese, Kristeva suggests that the written language embodies the oedipal-Confucian suppression of the preoedipal echolalia present in the intoned spoken language.

La logique de l'écrit . . . laisse présupposer, à la base, un sujet parlantécrivant pour lequel ce qui nous apparaît aujourd'hui comme une phase pré-oedipienne, dépendance du continuum maternel et socio-naturel, absence de coupure nette entre ordre des choses et ordre des symboles, prédominance des pulsions inconscientes,- - aurait eu une importance majeure. L'écriture idéographique ou idéogrammatique s'en sert pour les buts du pouvoir étatique, politique et symbolique, mais sans les censurer. Un pouvoir despotique qui n'a pas oublié ce qu'il doit à la mère et à la famille matrilinéaire qui l'a sans doute précédé mais de pas très loin. Hypothèse? Fantasme? (p. 61)

[The logic of (Chinese) writing . . presupposes, at its base, a speaking, writing individual for whom what seems to us today a pre-oedipal phase-dependency on the maternal, socio-natural continuum, ab- 
sence of clear-cut divisions between the order of things and the order of symbols, predominance of the unconscious impulses-must have been extremely important. Ideogrammatic or ideographic writing makes use of this (pre-oedipal phase) for the ends of state, political, and symbolic power, but without censuring them. A despotic power that has not forgotten what it owes to the mother and the matrilinear family that has certainly preceded it, though not by long. Hypothesis? Fantasy?]

In equating the intoned rhythms associated with the pre-oedipal phase of mother-child union with the ancient, prepatriarchal phase of Chinese history, Kristeva creates a deliberate confusion and conflation of the paradigms of individual psychology and language acquisition, the history of language and civilization. Furthermore, the argument that the intoned quality of Chinese language is evidence that the motherchild union was valued in ancient China is, to say the least, deluded exaggeration; indeed, a great number of contemporary spoken languages are intoned. Although the paradox of an intoned spoken language and a highly coded written language is noteworthy, Kristeva makes extremely speculative use of this paradox in suggesting that the independent system of written ideograms represents a later attempt to repress the ancient maternal tones. Finally, by romanticizing the Chinese language as a system of codes within which one can read about an earlier, tonal, pre-oedipal society which has survived the later symbolic ordering of written language, Kristeva casts the Chinese linguistic example as the semiosis she elsewhere suggests occurs in western poetics, in which the feminine pre-oedipal is brought into paternal language. ${ }^{9}$ The example of Chinese language, as it is constituted in Des chinoises, conveniently serves Kristeva's theory of the semiotic chora elaborated at length in La révolution du langage poétique. She subjects

In Révolution du langage poétique, Kristeva discusses the breaking of the Symbolic with the enunciation of "echolalic" or presymbolic tones, associating this phenomenon in avant-garde European poetry with the Chinese system of language. Poetry is described as a process of reinvestment in a maternal, semiotic chora that transgresses the symbolic order, or a genotext of semiotic processes which interrupts the communicative phenotext. Kristeva cites Mallarmé and Joyce as writers who are able to "reach the semiotic chora." The Revolution in Poetic Language, trans. Margaret Waller (New York: Columbia University Press, 1984); see sections 9-12 in "The Semiotic and the Symbolic," pp. 62-89.

"Women's Time," Signs 7, no. 1 (Autumn 1981): 13-35, represents a later statement of Kristeva's feminism which is also concerned with a radically different female location outside the masculine linear time of history and politics, and which emphasizes the sociosymbolic materiality of language and writing as well. 
Chinese language, like Chinese history and culture, to French linguistic and psychoanalytic paradigms; China is constituted as a utopian text ("Hypothèse? Fantasme?") which illustrates the answers to some pressing theoretical problems for the western semiotician.

Chapter 2, "Confucius_un 'mangeur des femmes,' " discusses the Confucian era, generalized and homogenized into a period ranging from 1000 B.c. to the twentieth century (the text does not become less imperializing). In Confucian society, the text argues, an oppressive backlash extensively excluded women by law and social hierarchy. This is compared to the western biblical and psychoanalytic oppression of western women, described in the first five chapters of part 1. Absolute language is used to express the oppression of women under Confucianism: "elles subissent l'autorité," "elles se soumettent à la nouvelle autorité des beaux-parents et des maris," "elles doivent une obéissance filiale absolue" (They are subject to authority, they submit themselves to the new authority of parents-in-law and husbands, they owe absolute filial piety and obedience; p. 82). The "pied bandé" (bound foot) is invoked as an ornate symbol of their profound capacity to obey. The absolute language of persecution calls attention to the polar opposition the text draws between the powerful position of women in the legendary ancient matriarchy and the extreme oppression of women under Confucianism. The developmental opposition between pre-Confucian and Confucian times puts forth a thesis about the history of Chinese woman which is analogous to the paradigmatic splits characterized by the notions of pre-oedipal and oedipal phases of human development. If Chinese women formerly had power and coequal status during the ancient period of Chinese civilization, the backlash against Chinese woman under Confucianism constitutes a "refoulement" like the psychoanalytic repression of the mother's "jouissance." Because Chinese women have a point of origin in which they were powerful and dominant, the repressed woman is described as both subject to authoritarian structures of obedience and simultaneously undetermined and outside those structures. Kristeva argues that the Chinese woman is at once within familial and social relations and yet beyond those relations, and that her hysterias, suicides, and pregnancies are statements of her power, and examples of the ways in which the Chinese woman under Confucianism protests her subjection and subverts paternal authority. 
Finally, chapters 3-6 discuss the conditions of women in the People's Republic of China. Kristeva concludes that contemporary women in China have liberated themselves and reemerged as fully autonomous political subjects in a restoration of the coequal status and power they had possessed in the original matrilinear and matrilocal society. Because of its matriarchal roots, the Chinese Revolution of 1949, the text asserts, was an antipatriarchal revolution; the socialist revolution in China, Kristeva argues, brought a fundamental revolution in the patriarchal family and in the roles of women. The essential premise is that throughout the history of Chinese women, "her" experience has been completely other than the experience of western women under patriarchy. Confucianism and feudalism are juxtaposed with monotheism and capitalism; western saints are contrasted with Chinese concubines. For if the Chinese woman is constructed as impenetrably and incomprehensibly different, then it is possible to constitute her as "outside" western socialization, not reducible to western binary and hierarchical classifications. Kristeva rhetorically juxtaposes European and Chinese women, as if in the act of writing an encomium to Chinese women as an exemplary exception to western oppressions of women her text posits a radical maternal "semiotic" otherness that surges up through the Symbolic order. The implicit recommendation of the text is that "feminine writing" ought to regard, praise, and write about Chinese women, for the identification with a position eccentric to western ideology constitutes a "revolutionary" political strategy for objecting to that structure.

Le rôle de La Révolutionnaire (ou Le Révolutionnaire): refuser tout rôle, pour au contraire, rappeler cette 'vérité' hors temps, ni vraie ni fausse, inencastrable dans l'ordre de la parole et du symbolisme social, écho de nos jouissances, de nos paroles en vertiges, de nos grossesses. Les rappeler comment?-En écoutant, en remarquant le non-dit du discours ... enrelevant ce qui, à chaque instance, reste insatisfait, réprimé, neuf, excentrique, incompréhensible, dérangeant l'entente des installés. (p. 43)

[The role of the revolutionary (female or male): to refuse all roles, in order, on the contrary, to summon this timeless "truth"-formless, neither true nor false, echoes of our jouissance, of our words spoken in delirium, of our pregnancies-into the order of speech and social symbolism. But how do we call it into being? By listening, by recognizing the unspoken in discourse . . . by calling attention at all times to whatever 
remains unsatisfied, repressed, new, eccentric, incomprehensible, disturbing to the status quo.]

The identification and alliance with the eccentric, the Other, the Imaginary, is valorized as a political strategy that challenges the structures of domination in the western social order. Furthermore, language is considered the material medium of the ideological apparatus, and therefore a material site of political practice and change; writing from a position within western ideology about a phenomenon outside western history and ideology is essentialized as a means of displacing that ideology. But in inventing and appropriating the place of "Chinese woman," Des chinoises erases the situations of women in contemporary China, the complex interrelation of certain qualified freedoms with remnants of centuries of sexual discrimination and oppression in family, professional, and political life. The Chinese woman is fetishized and constructed as the Other of western psychoanalytic feminism, a transcendental exception to the overstructured bind of women in western Europe. Des chinoises curiously reproduces the postures of desire of two narratives it ostensibly seeks to subvert: the narratives of orientalism and romantic courtship, whose objects are the "oriental" and the "woman."

\section{A Poetics of Escape: Roland Barthes}

As early as Mythologies (1957), French exoticism - and the fascination with the oriental world-is both object and topos in Barthes's work. In Mythologies French cultural texts and practices that constitute the oriental as exotic and Other are objects of semiological and mythological criticism (as in "Continent perdu"); in the same volume, however, rhetorical postures that exoticize the East are practiced by the mythologist as parts of a critical project or methodology (as in "Le monde où l'on catche"). It is the latter practice that is developed and elaborated in Barthes's work of the 1970s. His later elaboration of exoticism occurs in two forms: initially as a critical appeal to a text outside western signification-as in the references to Japanese judo in "Le monde où l'on catche" (1957), or the midcareer text valorizing Japanese cultural texts as antitheses of occidental culture, L'empire des signes (1970). The second form of the ironic use of exoticism as a critical 
strategy is exemplified by Alors la Chine? (1975), in which Barthes invents a writing posture that dramatizes the critic's subjective encounter with an oriental system that refuses western paradigms and ideologies. Paradoxically, Barthes's corpus commences with a politicized criticism of exoticism, yet ends with a greatly elaborated practice of this very posture.

The shift in Barthes's writing-from the targeting of orientalism as an object of criticism in the late 1950 s to the dramatic practice of orientalism as a writing strategy in the mid-1970s-marks the changes of emphasis in his larger critical project during this period. The semiological critique of orientalism as an ideological text and the practice of exoticism and/or utopianism as a post-structuralist method of subverting western ideology represent twin, although paradoxical, impulses in Barthes's work. The semiological critique of western institutions and signifying practices (one of the practices being orientalism and its relationship to the colonizing of Asians and North Africans) is very clear in his early writing. In the middle and late periods, however, Barthes comes to consider semiology itself central to western constructions of meaning; semiology has become an orthodoxy in its own right, an apparatus that produces more meaning. The theoretical and political problem for Barthes during the early 1970 is the dilemma of how to write in a way that will further a critique of western institutions and yet speak from a position which does not dominate or master (as a critical discourse such as semiology does), and which eludes appropriation by the logics of western signification and epistemology. Barthes attempts several writing practices for the purpose of opening up different utopian spaces in order to challenge the structural binarisms of the early semiology. His forays into noncritical discourse include a representation of a pre-Symbolic Imaginary space in the unstructured image repertoire of the autobiography Roland Barthes par Roland Barthes (1975) and the collected utterances of the lover's discourse in Fragments $d^{\prime}$ un discours amoureux (1977), as well as the book on Japan and the essay on China. ${ }^{10}$ In L'empire des signes Barthes dramatizes the western

\footnotetext{
10Steven Ungar's book Roland Barthes: The Professor of Desire (Lincoln: University of Nebraska Press, 1983) offers an interesting discussion of Barthes by Barthes and A Lover's Discourse. Other notable studies and assessments of Barthes include Stephen Heath, Le vertige du déplacement (Paris: Fayard, 1974); Annette Lavers, Roland Barthes: Structuralism and After (Cambridge, Mass.: Harvard University Press, 1982); Réda Bensmaïa, The Barthes Effect (Minneapolis: University of Minnesota Press, 1987); Paul Smith, Discerning the Subject (Minneapolis: University of Minnesota Press, 1988).
} 
traveler's desire for interpreted meaning when confronted with Japanese cultural texts-foods, literature, etiquette, urban design - that refuse to signify for the western reader. Alors la Chine? in a like manner conjures China as a space absolutely apart from western institutions and signifying logics. All four of these texts posit a space outside the symbolic semiological system; in Barthes and Fragments the space is designated as "maternal" and outside symbolic relationships determined by the Father. In L'empire and Alors, although no less maternal, this space is figured as an "oriental" space. Ironically, Barthes's attempt to resolve the dilemma of criticizing western ideology while escaping the tyranny of binary logic takes a form not unlike that of traditional orientalism: through an invocation of the Orient as a utopian space, Barthes constitutes an imaginary third position. The imagined Orient-as critique of the Occident-becomes an emblem of his "poetics of escape," a desire to transcend semiology and the ideology of signifier and signified, to invent a place that exceeds binary structure itself.

Having offered this sketch of the importance of the Orient as signifier for Barthes's, I turn now to a more detailed discussion of a few of the precise figurations of this poetics of escape. The early semiological Barthes_of Mythologies (1957) and Éléments de sémiologie (1965)—is concerned with the processes through which the literal meanings of common objects and practices are appropriated and encoded, through social function and usage, with mythic significations: for example, the practice of drinking wine has the literal function of refreshment-its "first-order" meaning-but the social usage of wine invests the practice with a "second-order" myth of symbolic participation in French nationalism ("Le vin et le lait"). Like the other demystifications of social symbols and practices, the piece "Continent perdu" criticizes the ethnographic expedition as object and site of the myth of exoticism, as well as the appropriation of the Orient-as-a-sign by the ideology of French nationalism.

In "Continent perdu" Barthes argues that the filmic representation of an ethnographic expedition to the Orient has the literal meaning of documenting European interest in the oriental world, with a secondorder level of signification as "exoticism," a cultural form for acknowledging and rendering acceptable colonialist ventures. Barthes suggests that exoticism works through the assimilation of the oriental 
world to French conventions. In the film the Orient visited by the anthropologists is represented as being superficially different, yet with an essence absolutely similar to that of the Occident; Buddhism is portrayed as sharing the formal features of a ubiquitous Catholicism, including nuns with shaved heads and rites in which monks kneel and confess to their superior. The final result of the expedition, which employs an occidental palette to "color" the Orient-"colorier le monde, c'est toujours un moyen de le nier" ("to color the world is always a manner of annihilating it")-is an erasure of the history and the specificity of the "native" culture: "En somme, l'exotisme révèle bien ici sa justification profonde, qui est de nier toute situation de l'Histoire" ("All told, exoticism here shows well its fundamental justification, which is to deny any contextualization by History"). ${ }^{11}$ Thus, in "Continent perdu" the mythologist criticizes the manner in which the film of an anthropological expedition represents the Orient as pure reflection of the Occident, how the cultural object of the voyage is mythically appropriated by the ideology of colonialism.

Even the early Barthes of Mythologies, however, appeals to the Orient as a "different text" which contrasts a western semiotic model of signification. In the piece "Le monde où l' on catche". Barthes analyzes the wrestling match as a text that stages, through a drama of adversaries, well-worn cultural themes: "Ce qui est ainsi livré au public, c'est le grand spectacle de la Douleur, de la Défaite, et de la Justice" ("What is thus displayed for the public is the great spectacle of Suffering, Defeat, and Justice"). ${ }^{12}$ The Japanese art of judo is posed in this piece as an opposite genre to wrestling: whereas the wrestling match is a display of excess, a choreography of roles and gestures, judo is described as an economy of moves used not to signify but to win; whereas defeat in wrestling must be apprehended as a long enactment of suffering, the loser in judo disappears immediately. This contrast is a praise of Japanese culture as much as it is a critique of wrestling as a French cultural text. Paradoxically, the formulation of praise is also exoticizing: the "coloring" of the oriental world Barthes criticizes in

\footnotetext{
11Roland Barthes, "Continent perdu," in Mythologies (Paris: Seuil, 1957), pp. 163, 165; translations from Mythologies, trans. Annette Lavers (New York: Farrar, Straus and Giroux, 1972), pp. 94, 96. All translations are from this edition.

${ }^{12}$ Roland Barthes, "Le monde où l'on catche," in Mythologies, p. 17; trans. Lavers, Mythologies, p. 19.
} 
"Continent perdu" is accomplished in this gesture toward judo. Although Mythologies expresses a position that is critical of orientalism as a cultural practice, the allusion to the Japanese social text of judo reveals the early coexistence of an orientalist interest in the East as an antidote to western signification.

The middle-period Barthes is represented by the book on Japan L'empire des signes (1970) and by Le plaisir du texte (1973) as well as essays from the period 1968-1971. ${ }^{13}$ During this period Barthes addresses doubts that semiology adequately describes how meaning and representation occur in language and culture. One of the central themes of these middle essays is that analytical or critical modes of writing of the sort practiced in Mythologies and Éléments are capable for the moment of demystifying the workings of ideology and commenting on the means by which ruling ideas are accepted as natural and proliferated as popular opinion, but that eventually critical modes of writing are appropriated by the very ideology or set of ruling ideas originally criticized. Barthes discusses this matter in structural terms of the critical discourse itself becoming another level of myth, a "third-order" meaning. In this sense Barthes revises his previous position on the concept of metalanguage. Metalanguage is not possible, he now declares, as one is always contained in language, its social circulation, and its production of meanings. Barthes argues that semiology, as a critical discourse analyzing the distinction between signifier and signified, has become in itself a myth, a reification, another ideology: "In other words, a mythological doxa has been created: denunciation, demystification (or demythification), has itself become discourse, stock of phrases, catechistic declaration . . . it is no longer the myths which need to be unmasked (the doxa now takes care of that), it is the sign itself which must be shaken." ${ }^{14} \mathrm{He}$ declares that new tasks, "a science of the signifier," (p. 166), will replace semiology. Thus, the object of study for the middle Barthes is no longer the cultural symbol; rather, he concentrates on reading as the production of multiple meanings (Le plaisir du texte of 1973 is the strongest representation of this emphasis), celebrating the moments and occasions when the institution of single meaning fails, when the overdetermination of the signi-

\footnotetext{
${ }^{13}$ The essays from 1968-1971 are collected in a volume translated into English by Stephen Heath, titled Image Music Text (New York: Farrar, Straus and Giroux, 1977).

${ }^{14}$ Roland Barthes, "Change the Object Itself," in Image Music Text, p. 167.
} 
fier-signified relationship is disrupted. Whereas the early Barthes is interested in parole, or in decoding mythical speech, the middle Barthes is interested in langue, the social space of language in process, the unlimited, plural deferral of meaning. Hence, in "From Work to Text" in Image Music Text), Barthes opposes the "work" (as static, canonized literary meaning) to the notion of the "Text" (as an irreducible, unending, "stereographic" weave of signifiers) for the purpose of furthering the notion of reading as the infinite production of meaning. The distinction between "l'oeuvre" and "le Texte" is a polemical one; they do not represent two different physical objects but rather two different notions of reading, one limited to a singular intended meaning, the other asserting an infinite polysemous simultaneity of meanings.

In the "autobiography" Barthes par Barthes, the crisis of the middle work is posed most succinctly: when semiology as a "counterideology" itself becomes part of a doxa, or ideology, then ideology and counterideology are seen to be mutually constitutive "reactive formations":

Formations réactives: une doxa (une opinion courante) est posée, insupportable; pour m'en dégager, je postule un paradoxe; puis ce paradoxe s'empoisse, devient lui-même concrétion nouvelle, nouvelle doxa, et il me faut aller plus loin vers un nouveau paradoxe. . . . Il faut donc s'en couper, introduire, dans cet imaginaire raisonnable, le grain du désir, la revendication du corps: c'est alors le Texte, la théorie du Texte. Mais de nouveau le Texte risque de se figer: il se répète, se monnaye en textes mats, témoins d'une demande de lecture, non d'un désir de plaire: le Texte tend à dégénérer en Babil. Où aller? J'en suis là.

[Reactive formations: a Doxa (a popular opinion) is posited, intolerable; to free myself of it, I postulate a paradox; then this paradox turns bad, becomes a new concretion, itself becomes a new Doxa, and I must seek further for a new paradox. . . . One must then sever oneself from that, must introduce into this rational image-repertoire the texture of desire, the claims of the body: this, then, is the Text, the theory of the Text. But again the Text risks paralysis: it repeats itself, counterfeits itself in lusterless texts, testimonies to a demand for readers, not for a desire to please: the Text tends to degenerate into Babel. Where to go next? That is where I am now.] $]^{15}$

15Roland Barthes, Roland Barthes par lui-même (Paris: Seuil, 1975), p. 75; translated from Roland Barthes by Roland Barthes, trans. Richard Howard (New York: Farrar, Straus and Giroux, 1977) p. 71. All translations are from this edition. 
Barthes poses the theory of the Text as an antidote to the "concretion" of semiology; a notion of a plurality of meaning challenges the tyranny of singular meaning. But, as this passage confesses, this "theory of the Text" also "risks paralysis"; it is in jeopardy of being fixed, deadened, co-opted. It is within the context of this dilemma that Barthes devises different writing practices to escape the collapse into doxa. After the theory of the plural Text, Barthes then attempts to imagine a site beyond opposites, beyond doxa and paradoxa. In Barthes par Barthes one of the designations for this space is atopia: "L'atopie est supérieur à l'utopie (l'utopie est réactive, tactique, littéraire, elle procède du sens et le fait marcher)" (p. 53) ("Atopia is superior to utopia [utopia is reactive, tactical, literary, it proceeds from meaning and governs it]"; p. 49). The book on Japan and the piece on China both represent this desire to invent "atopia," to devise new writing practices in order to escape the reactive formation of ideology and counterideology.

In keeping with the desire to imagine an "atopia," Barthes invents a mythical place named "Japan" in L'empire des signes: "Si je veux imaginer un peuple fictif, je puis lui donner un nom inventé, le traiter déclarativement comme un objet romanesque . . . de façon à ne compromettre aucun pays réel dans ma fantaisie ... que j'appellerai: le Japon" ("If I want to imagine a fictional people, I could give it an invented name, treat it openly like a novelistic object . . . so as to compromise no real country by my fantasy . . . which I shall call: Japan"). ${ }^{16}$ In this imagined country, not only do the particular social arrangements, language, and cultural practices represent a deviation from western forms of meaning, but also the western binarisms themselves-signifier and signified, inside and outside, self and Otherare thematized and undone by Japanese texts; these relationships essential to western meaning are thwarted and rendered unintelligible by the Japanese system. The experience of this Japan is described as being like a "dream" of learning another language in which occidental logic fails to signify:

Le rêve: connaître une langue étrangère (étrange) et cependant ne pas la comprendre: percevoir en elle la différence sans que cette différence soit

16Roland Barthes, L'empire des signes (Geneva: Skira, 1970), p. 13; translation from Empire of Signs, trans. Richard Howard (New York: Farrar, Straus and Giroux, 1982), p. 3. All translations are from this edition. 
jamais récupérée par la socialité superficielle du langage . . . défaire notre "réel" sous l'effet d'autres découpages, d'autres syntaxes . . . en un mot, descendre dans l'intraduisible . . . jusqu'à ce qu'en nous tout l'Occident s'ébranle et que vacillent les droits de la langue paternelle, celle qui nous vient de nos pères et qui nous fait à notre tour, pères et propriétaires. (p.13)

[The dream: to know a foreign (alien) language and yet not to understand it: to perceive the difference in it without that difference ever being recuperated by the superficial sociality of discourse ... to undo our own "reality" under the effect of other formulations, other syntaxes . . . in a word, to descend into the untranslatable . . . until everything Occidental in us totters and the rights of the "father tongue" vacillate-that tongue which comes to us from our fathers and which makes us, in our turn, fathers and proprietors.] (p. 6)

Barthes evokes Japan as an imaginary topos of "untranslatable" difference (just as the "Text" is earlier imagined as "irreducible" plurality). The imagination of Japan is an occasion to wish, as in a dream, the toppling of the West: the undoing of its systems of language and discourse, its institutions of meanings, its symbolic paternal order. In the dream-text of Japan, Barthes reads sukiyaki as "une nourriture décentrée," the Japanese face as "un signe vide," and celebrates the "nullité du sens" of Japanese Zen Buddhism. By creating the fictive text of Japan, Barthes ventures a possible resolution to the question battled in midlife: Where do critics go where they will not be determined by the very theories, the very texts, they have authored?

As antitext to the West, however, Japan is ultimately not an "atopia" but a "utopia": "réactive, tactique, littéraire." The desire to escape his own subjectivity, history, and language is quite evidently an oppositional desire, still caught within the binary logic he seeks to avoid. Japan is continually described with reference to the Occident, solely in terms of what the Occident is not: the Japanese city is decentered, Barthes claims, whereas Paris is oriented around a central place; chopsticks capriciously select, turn, and shift delicate pieces of food, whereas knives and forks cut, pierce, and dominate; Japanese Bunraku puppet theater fragments the components of the drama and reveals the puppeteers manipulating the puppets, whereas occidental theater is an art of simulating the "naturalness." of the human figure, of situating the origin of drama and emotion in the interior of the actor. Thus, in L'empire, as in the construction of judo in Mythologies, 
Barthes invokes Japanese cultural texts as antidotes to western institutions of meaning. In a sense, L'empire is structured as if it were a companion volume to Mythologies; for, as in Mythologies, the semiologist chooses cultural objects and practices to decode in terms of levels of denotation and connotation. In L'empire, however, the thwarted efforts of the semiologist are thematized. The semiologist discovers that the Japanese forms precisely do not mean, do not signify, in western terms. Barthes's invention of Japan is a reactive formation; its cultural texts are important to the degree that they do not conform to western systems of signification. In the discussion of the relationship between the paradigm of semiology and the theory of a polysemous Text, Barthes articulates the dilemma of reactive formation as one in which a paradoxa, erected as an antidote to a doxa, itself solidifies into a another doxa. In L'empire the utopian formulation of Japan, which represents an antithesis to western semiology, repeats this logic of reactive formation.

\section{Alors la Chine?: "Où aller? J'en suis là."}

Alors la Chine? (1975) is a much shorter, if no less "utopian," narrative about an invented Orient. Though not one of Barthes's more famous pieces, it is worthy of attention for not only does it develop further his search for a new form of writing, but also, along with Kristeva's Des chinoises, it emblematizes the powerful hold that China had on the imagination of certain French intellectuals during the mid1970s. Like the Japan of L'empire, China is also constructe 1 as a refutation of European hermeneutic and political traditions; the China evoked in this piece, however, elides the French writer's interpretive acts in a very different manner than does his Japan. In L'empire, even though the cultural texts are framed as ornate antitheses of French rites and practices, the Japanese texts are granted separate and independent symbolic logics (postulated, at times, as antilogics) of their own. In Alors, China is a text that completely lacks a symbolic function, is nothing but bland surfaces, contains no meanings to elucidate, no bodies to eroticize. It is constructed as offering only a single political Text, a set of coded clichés combined in various ways. The China described by Barthes is radically boring. 
To a much greater degree than L'empire, Alors thematizes the project of writing about an absolute site of difference as the central topos of a writing strategy. This thematization is a consequence of the bipartite structure of the published text. Divided into two sections, which represent two writing situations, the text contains a first part written in a descriptive present made and a second part in a retrospective imperfect tense. The beginning section simulates the voice of an occidental traveler who experiences China; the final section (in italics) consists of reflective remarks and assessments about having written about China, an afterword composed after the "original" publication of the beginning section in Le Monde.

In the first section of Alors, China is hallucinated as a culture whose impossible homogeneity refuses to signify in western terms. Throughout the piece the traveler-narrator implies an antithesis between the cultural systems of France and China: French culture is a society structured on difference, differences being the source of occidental desire, meaning, and eroticism. Chinese society, he argues, is neutral, smooth, and prosaic, profoundly lacking conflict or difference. The undivided homogeneity is asserted in numerous remarks about the conformity, the undifferentiated appearances of the people, as well as the lack of color, and the bland, faded quality of everyday life: "La Chine n'est pas coloriée. La campagne . . . est plate . . . au loin, deux buffles gris, un tracteur, des champs réguliers mais asymétriques, un groupe de travailleurs en bleu, c'est tout" ("China is not colorful. The countryside ... . is flat ... in the distance a few gray oxen, a tractor, orderly but asymmetrical fields, a group of workers dressed in blue, and that is all"). ${ }^{17}$ Yet it is precisely the peacefulness and tedium which are evoked as subversive and radically Other, insofar as they thwart the western subject's hermeneutic desire for closure, meaning, and correspondence.

Nous voulons qu'il y ait des choses impénétrables pour que nous puissions les pénétrer: par atavisme idéologique, nous sommes des êtres du déchiffrement, des sujets hermeneutiques; nous croyons que notre

\footnotetext{
${ }^{17}$ Roland Barthes, Alors la Chine? (Paris: Christian Bourgois, 1975), p. 9. I am grateful to Steven Ungar for having referred me to this text. The translation is by Lee Hildreth from "Well, and China?" Discourse 8 (Fall-Winter 1986-87): 116-21; the quoted passage appears on p. 117.
} 
tache intellectuelle est toujours de découvrir un sens. La Chine semble résisterà livrer ce sens, non parce qu'elle le cache mais, plus subversivement, parce que (en cela bien peu confucéenne) elle defait la constitution des concepts, des thèmes, des noms; elle ne partage pas les cibles du savoir comme nous; le champ semantique est désorganisé . . . les objets idéologiques que notre société construit sont silencieusement déclaré im-pertinents. C'est la fin de l'hermeneutique. (p. 8)

[We want there to be impenetrable phenomena, so that we can penetrate them: by an ideological atavism, we are deciphering beings, hermeneutic subjects. We believe our intellectual task is always to discover a meaning. China seems to resist delivering this meaning, not because it hides it, but more subversively, because (in this respect very un-Confucian) it defeats the constitution of concepts, themes, names. It does not divide up the targets of knowledge as we do; the semantic field is disorganized . . . the ideological objects of our society are silently declared im-pertinent. It is the end of hermeneutics.] (p. 116-17)

In defining China as "subversive," as not yielding to the western subject's desire for meaning, Barthes specifies that his notion of China is not one in which China hides meaning from the western observer (a configuration within which China would again be invoked as a "reactive formation," "tactical, literary"). Rather, he asserts, from the point of view of the separate and different China, western hermeneutic desires are simply irrelevant. Barthes, the traveler-narrator, figures China as that long-imagined nonreactive atopia, confronted by which occidental systems of meaning totter and fail.

Although the narrator takes elaborate pains to declare China an independent phenomenon, the rhetorical and syntactical logic of the narrative description performs exactly the opposite function. First, a characterization of the western paradigm precedes each definition of China, rhetorically rendering each perception of China's difference dependent on an aspect of western ideology. Second, in contrast to the active subjectivity of nous in the syntactical constructions that describe western desires_-"nous voulons," "nous sommes," "nous croyons" "la Chine" occurs persistently as the subject of negations, of dependent clauses and qualifiers. Logically and syntactically, China is subversive if considered exclusively in terms of occidental cultural systems; the narrator does not offer an explanation of how China is subversive within its own autonomous cultural system.

In a manner not unlike the invention of the mythical Japan, the 
subversive China is invoked according to a logic of opposition; it is described in terms of how it thwarts the will to decipher, and is described for the purpose of more thoroughly elaborating the western observer's hermeneutic desire. Even the description "bien peu confucéenne" does not denote an evolution or history within a specifically Chinese system of reference. For in this phrase "confucéenne" is appropriated to signify a hermeneutic "constitution des concepts, des thèmes, des noms." With this deft move Barthes snatches Confucian doctrine from China by equating it with western hermeneutics-stripping Chinese Confucianism of its lengthy history, condensing its myriad and diverse tenets into a single dimension-and assimilates it to an occidental characterization of itself.

There is another level on which Alors refuses to consider the independent status of China and relegates China to a position of serving the interests of the Occident; this is the tendency of the French leftist intellectual to make the Chinese communist example into a. political fetish. The remark "bien peu confucéenne" refers to one of the goals of the Chinese Revolution of 1949, as well as to the cultural reform programs up through the Cultural Revolution: that the Confucian ethos of maintaining social order through correct hierarchical relationships should be purged from Chinese culture. In this one parenthetical phrase Barthes constructs a China that has successfully achieved Mao's Cultural Revolution by placing professors, officers, and administrators in the fields and factories. But the history, the struggle, the labors of restructuring are rendered invisible, and the implications of this enormous Chinese project are collapsed and reduced into one significance: that the otherness of the Chinese political experience should serve as a reified utopian moment for the contemporary French Left in the wake of May 1968, the Parisian attempt at "cultural revolution."

In a further elaboration of the irreducible political experience of China, Barthes asserts that whereas western ideology "depoliticizes" social practice, the political text is absolutely explicit in China: "En somme, à peu de choses près, la Chine ne donne à lire que son Texte politique. Ce texte est partout: aucun domaine ne lui est soutrait" (pp. 10-11) ("In short, China offers very little to be read aside from its political Text. That Text is everywhere: no area is exempt from it"; p. 118). What does it mean to be a pure "political text"? The background to this enigmatic gesture is provided in a much earlier discussion in 
Mythologies, a discussion in which Barthes formulates an opposition between myth, or "depoliticized speech," and "political speech." Myth is depoliticized speech, he argues, because it represses the acts and processes of production, erasing ideological meanings, in order to represent the product and its values as both "natural" and "eternal." Yet, as early as Mythologies Barthes already gestures toward an essentialized kind of speech that is not susceptible to myth:

Si le mythe est une parole dé-politisée, il y a au moins une parole qui s'oppose au mythe, c'est la parole qui reste politique. Il faut ici revenir à la distinction entre langage-objet et méta-langage. $\mathrm{Si}$ je suis un bûcheron et que j'en vienne à nommer l'arbre que j'abats, quelle que soit la forme de ma phrase, je parle l'arbre, je ne parle pas sur lui. Ceci veut dire que mon langage est opératoire, lié à son objet d'une façon transitive: entre l'arbre et moi, il n'y a rien d'autre que mon travail, c'est-à-dire un acte: c'est là un langage politique; il me présente la nature dans la mesure seulement où je vais la transformer, c'est un langage par lequel j'agis l'objet: l'arbre n'est pas pour moi une image, il est simplement le sens de mon acte....

Il y a donc un langage qui n'est pas mythique, c'est le langage de l'homme producteur. ... Voilà pourquoi le langage proprement révolutionnaire ne peut être un langage mythique. . . . La bourgeoisie se masque comme bourgeoisie et par là même produit le mythe; la révolution s'affiche comme révolution et par là-même abolit le mythe.

[If myth is depoliticized speech, there is at least one type of speech which is the opposite of myth: that which remains political. Here we must go back to the distinction between language-object and metalanguage. If I am a woodcutter and I am led to name the tree which I am felling, whatever the form of my sentence, I "speak the tree," I do not speak about it. This means that my language is operational, transitively linked to its object; between the tree and myself, there is nothing but my labor, that is to say, action. This is a political language: it represents nature for me only inasmuch as I am going to transform it, it is a language thanks to which I "act the object"; the tree is not an image for me, it is simply the meaning of my action. ...

There is therefore one language which is not mythical, it is the language of man as a producer. . . This is why revolutionary language proper cannot be mythical. . . . The bourgeoisie hides the fact that it is the bourgeoisie and thereby produces myth; revolution announces itself openly as revolution and thereby abolishes myth. $]^{18}$

${ }^{18}$ Barthes, Mythologies, pp. 233-34; Mythologies, trans. Lavers, pp. 145-46. 
As opposed to depoliticized speech, the labor of a specific worker acting upon an object is an enunciation of revolutionary "political speech." In asserting that this act in which the woodcutter speaks the tree can be invulnerable to myth-and is not subject to the repression of production or the erasure of history, which are functions of the metalanguage of myth-Barthes suggests that "political speech" does not conform to the outlined system of semiotic signification; indeed, this passage suggests that political speech is so powerful that it can "abolish myth." Earlier Barthes had argued that the arbitrariness of the sign - that is, the arbitrary, divisible, and relative relationship between any signifier and signified-makes most language objects vulnerable to invasion by the signification of myth. Here he suggests, however, that "political speech" is invulnerable because it is a special language object. There is an implied association of the semiotic sign constituted by political speech, which is indivisible and not arbitrary, and the notion of unalienated labor before the worker's labor is alienated and extracted as the surplus value of the product. ${ }^{19}$ The act of the woodcutter upon the tree is pure political speech because, like the notion of unalienated labor, it is not yet separated from its object. Barthes's declaration that "revolution announces itself openly as revolution and thereby abolishes myth" suggests that a state of revolution might consist of the continual enunciation of political speech, in which speech could not be alienated from labor, and labor could not be alienated from the worker.

In the context of this earlier distinction between depoliticized (mythical) speech and political speech in Mythologies, it is possible to understand that Alors la Chine? celebrates China as a utopian site where this pure political speech is pronounced and iterated-everywhere. In China, Barthes contends, the political text is at one with social relations: with no mediation or gap between them, the sign is the referent.

\footnotetext{
${ }^{19}$ The notions of alienated and unalienated labor are elaborated in Marx's early writing, "The Economic and Philosophical Manuscripts of 1844." Marx argues that the worker's labor is alienated in the object of the product when the product of the worker's labor is appropriated by the owner of the means of production to earn profits from the surplus value of that product. "Through estranged, alienated labour, then, the worker produces the relationship to this labour of a man alien to labour and standing outside it. The relationship of the worker to labour engenders the relation to it of the capitalist, or whatever one chooses to call the master of labour. Private property is thus the product, the result, the necessary consequence, of alienated labour, of the external relation of the worker to nature and to himself." Marx-Engels Reader, p. 65.
} 
Ai-je parlé de fadeur? Un autre mot me vient, plus juste: la Chine est paisible. La paix (à quoi l'onomastique chinoise fait si souvent référence) n'est-elle pas cette région, pour nous utopique, où la guerre des sens est abolie? Là-bas, le sens est annulé, exempté, dans tous les lieux où nous, Occidentaux, le traquons; mais il reste debout, armé, articulé, offensif, là où nous répugnons à le mettre: dans la politique. (p. 10)

[Did I speak of blandness? Another word comes to me, one that is more accurate: China is peaceful. Is not peace (to which Chinese onomastics makes such frequent reference) the region, utopian for us, where the war of meaning is abolished? In China, meaning is annulled, exempted from being in all those places where we Westerners track it down, but it remains standing, armed, articulated, and on the offensive where we are loath to put it: in politics.] (p. 118)

Thus, China provides a utopian site for Barthes, outside both the western "war of meaning" and the "war" of industrial capitalist production. It is an impossibly inaccessible Other for both aspects of Barthes's desire-for the semiotician who imagines an irreducible "semioclasm," as well as for the leftist intellectual who envisions an ideal model of cultural revolution where there is "un mouvement par lequel on empêche continûment la révolution de s'épaissir, de s'engorger, de se figer" (p. 11) ("a movement by means of which the revolution is continuously kept from losing its momentum, from choking on itself, from congealing"; p. 119). China-as semiotic and political utopia-is the sign under which Barthes's "poetics of escape" is written.

With the addition of a brief afterword to the text, Barthes complicates the first section by commenting on it. By writing about the first section from a different temporal location, he splits the text as a whole and renders it divided, troubled. The first section dramatizes the western subject's desire; the second section (in the past tense) frames the present tense of the first as a spontaneous utterance, proclaims it a discursive site, interprets it. In this sense the formal structure of the published text itself is ambivalent; it cannot be reduced to one mode or the other but is always divided, never static, always doubled.

In this second section the reflexive Barthes interprets the project of the narrator of the first section: "Sur la Chine, immense objet et, pour beaucoup, objet brûlant, j'ai essayé de produire—c'était là ma véritéun discours qui ne fut ni assertif, ni négateur, ni neutre: un commen- 
taire dont le ton serait: no comment" (p. 14) ("About China, an immense object, and for many, an urgent one, I tried to produce-and this was my truth-a discourse that was neither assertive nor negative, nor neutral: a commentary whose tone would be no comment"; p. 120). The afterword states the first narrator's wish for a mode of writing that would neither praise nor condemn, and thus could not be absorbed into either a doxa or a paradoxa. But there is an evident contradiction between what the second narrator declares and what the rhetorical logic of the first narration reveals. Despite the descriptions of China as bland, boring, and homogeneous, the evocation of China is nonetheless invested, committed, desiring; the entire piece is structured as an encomium praising the very subversive "fadeur" of China. For example, the statement "la Chine n'est pas coloriée" does not impartially comment that China is "uninteresting." On the contrary, it precisely posits China in opposition to the pervasive and overdetermined occidental systems of signification; "la Chine n'est pas coloriée" is a manner of saying that China is not "colonized" (colorier recalls the piece on exoticism, "Continent perdu," in which colorier is the means through which cultural domination takes place), and therefore offers to the western subject one pure, irreducible site from which western ideology can be criticized. The encomium constitutes China as a place of impossibility, the desire for which initiates and sustains the writer's writing. The project of writing about this inconceivably homogeneous Other is like the "discours amoureux," fragments uttered for a beloved whose absolute silence refuses the lover's words. It is the writing about the desired figure that founds the voice of the writer, and the closed inpenetrability of this Other that maintains the writing project, inasmuch as the Other can never be wholly written about. Again, as in traditional orientalism, the western writer's desire for the oriental Other structures the Other as forever separated, unpossessed, and estranged.

In the afterword to Alors la Chine? Barthes characterizes his aims and methods in the preceding narrative's description of China:

En hallucinant doucement la Chine comme un objet situé hors de la couleur vive, de la saveur forte et du sens brutal (tout ceci n'étant pas sans rapport avec la sempiternelle parade du Phallus), je voulais lier dans un seul mouvement l'infini féminin (maternel?) de l'objet lui- 
même, cette manière inouie que la Chine a eue à mes yeux de déborder le sens, paisiblement et puissamment. (p. 14)

[By gently hallucinating China as an object located outside any bright color or any strong flavor, any brutal meaning (all this not without a bearing on the relentless parade of the Phallus), I wanted to bring together in a single movement the infinite feminine (maternal?) of the object itself, that extraordinary way China, in my eyes, had of overflowing the boundaries of meaning, peacefully and powerfully.] (p. 120)

If the first section of Alors emphasized China's otherness as a pure political text outside the logic and process of western signification, the remarks in the afterword figure China's otherness in psychoanalytic terms, and within a psychoanalytic paradigm. Barthes's association of China's "débordement" of western meaning with a feminine or maternal disruption of a phallic order locates China with reference to the Lacanian notions of the maternal Imaginary and the realm of the paternal Symbolic. Here we observe an interesting parallel between Barthes's and Kristeva's formulations. Kristeva places Chinese women in a pre-oedipal phase anterior to the castration and oedipalization that she associates with the processes of signification and subjectification in the sociosymbolic West. Like Kristeva, Barthes also makes use of Lacanian distinctions in order to posit a presymbolic space outside the Symbolic system based on the possession of, lack of, or desire for the masculine signifier of the phallus. ${ }^{20}$ Both critics emphasize the nonintelligibility of western language within the context of their fictions of China in order to liken China to a preverbal psychoanalytic space, a site outside language and before the intervention of the Father. As the foregoing passage illustrates, this site is associated with the maternal, constituted by both Barthes and Kristeva as a powerful force for interrupting the overdetermined structures of relationship in the paternal Symbolic. Insofar as Barthes and Kristeva rely on the concepts of the Imaginary and the Symbolic in constructing the otherness of China, they situate China in a space akin to the Imaginary,

\footnotetext{
20In a sociological study of the emergence of psychoanalytic culture in France during the 1970s, Psychoanalytic Politics: Freud's French Revolution (Boston: Basic Books, 1978), Sherry Turkle analyzes the social circumstances that allowed the work of the psychoanalyst Jacques Lacan to exert such an influence on the thinking and politics of leftist intellectuals and literary theorists. The social revolts of May-June 1968 are central to Turkle's explanation of the particular form of psychoanalytic culture in France.
} 
which Lacan poses as prior to, and recapitulated from, the sociolinguistic Symbolic.

In a sense, Barthes's projection of China in the first half of Alors as Other to western hermeneutics and politics coincides with the early desires in Mythologies and the middle-period desires of "La mythologie aujourd-hui" to locate a sociolinguistic position that is not subject to the overdetermination of western language, ideology, and practice. When Barthes associates this space with the "feminine" in Alors, and designates it as maternal and antiphallic, the frame of reference changes from a sociolinguistic one to one that is primarily psychoanalytic. Barthes's privileging of the psychoanalytic framework is what finally dehistoricizes and depoliticizes China, and ultimately reduces China's vast and heterogeneous history to an essentialized category within western psychoanalytic explanation. Indeed, one notes a methodological shift that privileges psychoanalysis, as opposed to the earlier sociolinguistic methods of semiotics, in the middle and later texts. The reduction of China to the maternal Imaginary in Alors is one telling example of the methodological shift in the larger corpus as a whole.

Some of the implications of Barthes's association of China with these psychoanalytic categories become clearer if we locate these categories in the middle works-Fragments d'un discours amoureux, Barthes par Barthes-and especially in the later work La chambre claire (1980). In these texts, as in Alors, Barthes constitutes maternal otherness as an irreducible difference against which social, linguistic, and ideological systems of meaning are distinguished. Barthes's texts consistently appeal to the presocial or extrasocial energies and desires of the maternal and the Imaginary in order to disrupt the Symbolic's order of meaning and law. In both Fragments and Barthes par Barthes, Barthes invents an Imaginary presocial order as part of devising writing strategies that oppose the paternal Symbolic order. ${ }^{21}$ Both writing projects-Fragments and Barthes-metaphorically suspend the period of the Imaginary by refusing narrative, argument, or hierarchizing logics. Both texts associate the Imaginary with the Mother, and with a realm

\footnotetext{
${ }^{21}$ Gregory Ulmer, "The Discourse of the Imaginary," Diacritics 10, no. 1 (March 1980): 61-75. Ulmer asserts that in Barthes and A Lover's Discourse, Barthes attempts to open a "third front" in criticism, devising a "projective-productive style of reading" in which the relationship of reader and text imitates the Imaginary relationship of child-subject and Imaginary Other.
} 
outside the sociosymbolic network of inscription and signified subjectivity.

The "figures" in Fragments dramatize a variety of possible desiring postures of the subject in love; they are presented in a random, nonlinear, nonexclusive order, as if the text were a simulation of the various topoi of desire that hover before speech in the unconscious. Fragments suggests that "love" occurs in the junction between the Imaginary and the Symbolic, that is, in the transitions between the preverbal and presocial desires (of child for Mother, for specular images, for absent others) and the articulation of this desire in the symbolic system of speech and language. The text portrays the source of the "lover's discourse" in the Imaginary, before selection, before being inserted into a narrative. Fragments, however, presents the lover's possible utterances as ends in themselves. Unhierarchized and coequal, they are suspended without emplotment, without destination. Barthes par Barthes is a somewhat random collection of fragments as well, simulating a presymbolic "antistructure" or "polygraphy" of photographic images, meditations, and aphorisms that makes up the "life" of Roland Barthes. The structure of the book simulates an Imaginary consisting of assorted visual images and aphorisms; the text places the reader in the position of analyst, or of secondary revisionist, by its demands on the reader to pull together the fragments, to interpret, to infer and consolidate. Associative connections are substituted for narrative logic; a diffused, shifting, fragmented voice-at times referred to as "je," at times as "il" or "R. B." —is substituted for a unified and oedipalized subject. In thematizing the Imaginary as those images before language, narrative, and oedipalization, the writing strategies of Fragments and Barthes metaphorically defer the processes of castration and socialization associated with entry into the Symbolic. In these texts, oedipalization is effectively displaced as the destination or end point of writing and narrative.

La chambre claire, the eulogy to Barthes's mother, finished just before his own death, also evokes a maternal realm, appealing to an impossible and irreducible maternal body which radically interrupts the social system. In La chambre the photograph is explored as a form of presentation, as opposed to representation, that is not subject to language, analysis, ideology; the meditation on the photograph is a vehicle for isolating and articulating a phenomenon that can be classified as prelinguistic. The shift to essentialized psychoanalytic categories, which 
marks both the later works and the final characterization of China in Alors, is perhaps best exemplified by the concept of the photographic punctum. Barthes asserts that an inexplicable element in the photo may trigger an inexpressible and overwhelming constellation of presocial desires, memories, and mourning. The punctum is a detail in a photograph-for Barthes it is a man's fingernails in one photo, a woman's shoes in another-that "punctures" the viewing subject and triggers a subjective experience. The punctum initiates a powerful contradiction in the viewer of the photo; suddenly the viewer is seized by the sense that although the photograph may declare the absolute presence of the person, place, or event in the photo, it is simultaneously an undeniable statement of the photographed subject's absence, the fact of its no longer existing as it does in the photo: "Le punctum, c' est: il va mourir. Je lis en même temps: cela sera et cela a été; j'observe avec horreur un futur antérieur dont la mort est l'enjeu. . . . Devant la photo de ma mère enfant, je me dis: ella va mourir" ("The punctum is: he is going to die. I read at the same time: This will be and this has been; I observe with horror an anterior future of which death is the stake. . . Before the photo of my mother as a child, I tell myself: she is going to die" ${ }^{\prime 2}{ }^{22}$ Although different details and photos initiate the wounding paradox of the punctum for different individual viewers, the "original source" of the punctum, Barthes implies throughout, is the viewer's memory of the maternal body. Viewing Charles Clifford's photograph of a Mediterranean house, the Alhambra, Barthes declares:

Il est fantasmatique, relève d'une sorte de voyance qui semble me porter en avant, vers un temps utopique, ou me reporter en arrière, je ne sais où de moi-même: double mouvement que Baudelaire a chanté dans l'Invitation au Voyage et La Vie Antérieure. Devant ces paysages de prédilection, tout se passe comme si j'étais sûr d'y avoir été ou devoir y aller. Or Freud dit du corps maternel qu' "il n'est point d'autre lieu dont on puisse dire avec autant de certitude qu'on y a déjà été." Telle serait alors l'essence du paysage (choisi par le désir): heimlich, réveillant en moi la Mère (nullement inquiétant). (p. 68)

[It is fantasmatic, deriving from a kind of second sight which seems to bear me forward to a utopian time; or to carry me back to somewhere (I don't know where) in myself: a double movement heralded by Baude-

\footnotetext{
22Roland Barthes, La chambreclaire: Note sur la photographie (Paris: Editions de l'Étoile, Gallimard, Seuil, 1980), p. 150; translation from Camera Lucida, trans. Richard Howard (New York: Farrar, Straus and Giroux, 1981), p. 96. All translations are from this edition.
} 
laire in Invitation au voyage and La Vie Antérieure. Looking at these landscapes of predilection, it is as if I were certain of having been there or of going there. Now Freud says of the maternal body that "there is no other place of which one can say with so much certainty that one has already been there." Such then would be the essence of the landscape (chosen by desire): heimlich, awakening in me the Mother (and never the disturbing Mother).] (p. 40)

In this description of the punctum, Barthes constitutes the maternal body as a fantasmatic yet essential site of origin. The viewer of the photograph is struck by a particular detail or aspect, something which is not perhaps even visually explicit, but which carries the viewer back to a notion of the mother's body. This experience is "uncanny" - that is, paradoxical, split—because this memory of the mother's body is at once immediately tangible in the subject's experience of the photograph and yet impossibly lost and immaterial. In this sense Barthes privileges the remembrance of the Mother as the prototypical punctum, and essentializes the Mother as origin. Throughout the text Barthes suggests that the punctum is crucial to the viewing subject's grasp of itself as subject, as existing. The phenomenological argument about the maternal body as the source of the punctum collapses back into a psychoanalytic argument about the Mother as the subject's first love and first source of love, before oedipalization and the intervention of the Father. As in other of Barthes's texts, the maternal is designated as a privileged and essentialized realm outside of, and more powerful than, sociosymbolic relations. ${ }^{23}$

Therefore, when the afterword to Alors la Chine? refers to "l'infini féminin (maternel?)" of China, which has no "rapport avec la sempiternelle parade du Phallus," Barthes is situating the binarism of China and the West in an already familiar system of psychoanalytic terms: China occupies a maternal, Imaginary, unnarrativized space antithetical to the sociosymbolic paternal order exemplified by the West. The remarkable irony of this figuration of China as Other is that even though the early essays in Mythologies criticize the binary logic that invented oriental cultures as the antithesis of western societies, in Alors a version of this very logic continues to structure the evocation of

${ }^{23}$ Lynn Higgins points out that foreign cultures are consistently experienced as maternal in Barthes's travelogues. See "Barthes's Imaginary Voyages," Studies in TwentiethCentury Literature 5, no. 2 (Spring 1981): 157-74. 
China in terms of a psychoanalytic binarism: China as maternal Imaginary and West as paternal Symbolic.

China is, in the binary logic of Alors, a fetish, in both the psychoanalytic sense of being a fixation, a repetition of the same illusion or disavowal, and the sense of being reified, as Marx writes of the fetishism of commodities in capitalist society. Freud discusses fetishism as the result of a splitting of the ego; it manifests itself in a fixation that allows a person to hold simultaneously two contrary beliefs. Freud cites the example of the male subject who disavows the sight of female genitals because the lack of the penis initiates his fear of castration; thus, he denies his own perception that female genitals lack a penis. Yet the disavowed perception is not without its own influence; although the subject cannot assert that he actually saw a penis, he substitutes (fetishizes) another part of the body, or another object, and assigns it the role of the penis. "The creation of the fetish was due to an intention to destroy evidence for the possibility of castration, so that fear of castration could be avoided." 24 Marx also uses the term fetishism to refer to the commodity form in capitalist society, particularly the process through which the value of the commodity on the market is a reification and mystification of the material and labor that went into producing the commodity. 25 Thus, when I refer to China as a fetish in Barthes's texts, I am referring both to the sustaining of two opposed systems of contrary beliefs and to the reification of China as a commodity/image for all that is subversive to western signification. For Barthes, on the one hand, western sociosymbolic relations are allpervasive and determining; yet on the other hand, each of his texts since Mythologies insists there must be a site that is not determined by these relations-an "uncastrated" speech, an undifferentiated society, without hierarchy, outside western law. Furthermore, in each of these texts the sign for this utopian space is both reified and mystified; in rendering China a transcendent Other, he allows little correspondence between the China of Alors and the historical circumstances of struggle and change in the People's Republic of China.

\footnotetext{
${ }^{24}$ Sigmund Freud, An Outline of Psycho-Analysis (New York: Norton, p. 60). See also J. Laplanche and J.-B. Pontalis, "Splitting of the Ego," in The Language of Psycho-Analysis (London: Hogarth, 1973).

${ }^{25}$ Fetishism in Marx is introduced in the "Economic and Philosophic Manuscripts of 1844," in Marx-Engels Reader, as well as in Capital; see pt. 1, chap. 1, "Commodities" (New York: International, 1967). For a detailed discussion of the fetishism of commodities in Marx, see White, Metahistory, pp. 287-97.
} 


\section{China as Political Utopia: Tel quel, Mai '68, and} French Maoism

In attempting to place Barthes's and Kristeva's formulations of China in the context of each critic's theoretical project and agenda, I have discussed Kristeva's notion that ancient Chinese matriarchy represented a pre-oedipal linguistic and social moment in the context of structuralist, psychoanalytic, and feminist debates of the period, and have placed Barthes's figuration of China as pure maternal speech in terms of the critical aims of his larger corpus. A third context for these figurations of China can be found in the political circumstances in France during the 1960s and early 1970s, particularly the revolutionary events of May 1968, as well as the subsequent attempts to grapple, politically and theoretically, with the significance of those events. In the aftermath of the widespread student revolts that were coordinated with massive workers' strikes in May 1968, critics and activists debated whether the crisis signaled a new age of European revolution or resulted in the consolidation of authoritarian rule. Numerous accounts asserted that May 1968 created "revolutionary possibilities," and that the events had suggested for the first time (as Marx had indicated in the Communist Manifesto) that revolution could occur in an industrialized European nation. ${ }^{26}$ At the same time, other analyses weighed more heavily the ultimate repression of the revolts, the failures of the Popular Front and the Communist party, and finally the recovery and swift electoral victory of the Gaullists in June. ${ }^{27}$ It is in the context of the judgments of the May events as a failure of revolutionary possibilities that one faction of leftists, intellectuals, students, and workers admired the People's Republic of China, constituted the Chinese Cultural Revolution as an example for the French Left, and celebrated Maoism as true revolutionary theory. Within this context the journal Tel quel provides another figuration of China-compatible with, yet inflected differently from, Kristeva's and Barthes's figurations-as ab-

26See Daniel Singer, Prelude to Revolution: France in May 1968 (New York: Hill and Wang, 1970), and George Katsiaficas, The Imagination of the New Left: A Global Analysis of 1968 (Boston: South End Press, 1987), which celebrate May 1968 in France in terms of its importance to the history of Eurocommunism.

${ }^{27}$ Critics who underscored the failures of the potential of May 1968 include Jean-Paul Sartre, André Barjonet, Jean-Marie Vincent, and Alain Touraine. 
solute political utopia, the Maoist Other of western Marxist theory and practice.

The Communist party of France (PCF, Parti communiste français) has a very different status and history from that of communist parties elsewhere, particularly in the United States. The strength and credibility of the PCF following the Second World War had much to do with the persuasiveness of the Marxist analysis of fascism and Nazism, as well as the PCF's role in the Resistance, and in leading union activity. In the period from 1945 to 1970 , however, both the theory and the practice of traditional French Marxism and French communism were challenged. Critiques of traditional Marxism, disillusionment with Soviet communism, and fragmentation of the French communist parties during the 1950 s made Chinese Maoism in the 1960s an attractive alternative for a section of the French Left. The example of the Cultural Revolution, which placed professors, officers, and administrators in the fields and factories on the principle of reconnecting the government and the masses, provided a theoretical coherence for the fragmented parties.

On a theoretical level, well-known radical critiques of traditional Marxism were carried out by Jean-Paul Sartre, Henri Lefebvre, Cornelius Castoriadis, and others. Sartre's existential critique of Marxism concerned itself with what he considered to be the lack of a Marxist theory of subjectivity; Lefebvre's revisionist critique questioned the traditional Marxist view of advanced industrial society; the gauchiste Castoriadis criticized authoritarianism and hierarchy in the communist bureaucracy, ultimately claiming that revolutionary Marxism had ossified into a bureaucratic ideology. ${ }^{28}$ These critiques contributed to the disillusionment of some students, workers, and intellectuals with the theory, policies, and machinery of the traditional PCF. Some older communists concerned about French involvement in Algeria and Indochina (of which the PCF was not greatly critical), and those disillusioned with Stalin and Soviet communism, considered Maoism an alternative to the orthodox stance of the PCF. Because the PCF dominated the CGT (Confédération générale du travail), the largest of the three major labor unions, the gauchistes viewed the PCF as a bureau-

\footnotetext{
${ }^{28}$ Arthur Hirsh, The French New Left: An Intellectual History from Sartre to Gorz (Boston: South End Press, 1981).
} 
cratic machine interested in integrating the working classes into the status quo. Other factions that were disenchanted with, or had been expelled from, the PCF looked toward "antihierarchical" Maoism for theoretical and organizational ideals. ${ }^{29}$ The social upheaval of May 1968 was an essential turning point in the challenges to traditional communism, for the themes of May were the very ones raised by the leftist critiques of Marxism: antihierarchicalism, self-management, the revolt against alienation in a bureaucratic society. At the same time, the events of May also seemed to reveal some of the limitations of both traditional Marxism and its new leftist critiques and in this sense represent an origin of the turn toward Maoism by Tel quel.

In 1968 the range of revolutionary activities against the Gaullist government which called for the dramatic expansion of freedoms for students and workers was neither singular nor peculiar to France. This was a time of popular protest in many nations; in Washington, D.C., Chicago, and San Francisco students and other citizens demonstrated against the involvement of the United States in the Vietnam war. In Rome, London, Tokyo, and Prague as well, dissident groups were spontaneously challenging ruling establishments. ${ }^{30}$ In France, student demonstrations in the universities began at Nanterre and spread across the nation. Students occupied universities and issued a farreaching critique of the university system which included specific protests against the authoritarian structure of the university (admissions policies, the repression of political meetings, examinations, the faculty rank system) and denunciations of the curriculum. But, unlike in the United States, for example, the French students were joined by

\footnotetext{
${ }^{29}$ At this particular historical juncture Maoism captured the imagination of a number of French radical groups: the Parti communiste Marxiste-Léniniste de France (PCMLF), the Union des étudiants communists (UEC) and its later Union des jeunesses communistes-Marxiste-Léniniste" (UJC-ML), the Gauche prolétarienne (GP), and Vive la Révolution (VLR), from which grew the feminist movement, Mouvement de libération des femmes (MLF), and the gay movement, Front homosexuel d'action révolutionnaire (FHAR).

For a short history of French Maoism, see Beldon Fields, "French Maoism," in The Sixties without Apology, ed. Sohnya Sayres et al. (Minneapolis: University of Minnesota Press, 1984).

${ }^{30}$ Two accounts of the global phenomenon of 1968 represent different tendencies in the interpretation of the events of that year. David Caute's Year of the Barricades (New York: Harper and Row, 1988) is somewhat more revisionist in its approach, whereas George Katsiaficas's Imagination of the New Left represents a more decidedly socialist interpretation.
} 
workers who occupied factories and subsequently organized a twoweek general strike affecting all industry, services, and trades. By May 13 workers had occupied factories throughout France; soon after, factory workers were joined by the public sector of industry-the railways, postal services, and airlines-as well as workers in services and trades such as hotels, banks, restaurants, and gas stations. The general strike of May 1968 resulted in a political crisis which so dramatically shook the structure of Gaullist power that the government retaliated with desperate and brutal repression. On June 1 the government stepped up the police and military suppression of demonstrations and occupations, while the unions negotiated with the government to stop the strikes, industry by industry; by June 6 workers in public transportation, mining, and some factories were forced to resume work. Ultimately, President Charles de Gaulle opportunistically invoked the threat of "totalitarian communism," just as the FGDS (Fédération de la gauche démocratique et socialiste) was in the midst of an organizing effort to launch the leftist coalition of the Popular Front. In the general elections at the end of June, the PCF and the FGDS lost over 10 percent of their votes, while the Gaullists (UDR, Union pour la défense de la République) gained almost 20 percent and were returned to power with an unmatched victory. The Left did not recover power until 1981 with the election of the Socialist PSU (Parti socialiste unifié) candidate, François Mitterrand.

For leftist intellectuals and students, the suppression and ultimate failure of the promising May events exacerbated their disillusionment with the French Communist party. The PCF and its paper L'humanité had not supported the student revolts; the party's traditional emphasis on the proletarian class as the only revolutionary class had led the PCF to condemn the uprising as petit-bourgeois anarchism, thus greatly alienating students and intellectuals. The party had argued that they chose to behave in an orderly electoral manner because the situation had not been revolutionary. Disappointed by the outcome of the May efforts, some Marxists criticized the PCF's shunning of the popular movement in favor of electoral politics, and credited the PCF with making possible the Gaullist repression and electoral victory. It must be said that the French communists in 1968 received blame from both sides: they had sufficient organizational strength and numbers to be scapegoated as a threatening specter by General de Gaulle, and at 
the same time severe criticisms fell on them from the Left. Sartre, JeanMarie Vincent, and André Barjonet charged that the PCF had misunderstood both the aims and the means of the revolution, that it was doctrinal rigidity that had refused to accord importance to the student insurrections, and finally, that the emphasis on electoral politics implied less a reversal of the Gaullist regime than a friendly transmission of power from one party apparatus to another. ${ }^{31}$ Furthermore, as a result of the CGT's efforts to harness the workers' strikes and to separate them from the student movement, as well as the FGDS's electoral ambitions, certain leftist critics questioned whether western Marxism had not itself become part of the existing political system. Critics such as Philippe Sollers, Marcelin Pleynet, Jean Ricardou, JeanLouis Baudry, and Julia Kristeva, for whom the journal Tel quel was a center, sought to form a more radical Marxist critique of culture and society which would take its theoretical inspiration from a source outside western Marxism.

In this sense the journal Tel quel exemplifies an intellectual topos peculiar to Paris in the early 1970s, in which those leftist intellectuals disillusioned by 1968 came to consider the FGDS and PCF as agents for reinforcing the existing political system, and thus sought another kind of political model in Maoism and the Cultural Revolution. In $1971 \mathrm{Tel}$ quel constituted the People's Republic and the Cultural Revolution as absolutely nonoccidental phenomena, which, owing to their very situation outside western European political experience, represented a model for revolution and ongoing cultural criticism that could not be recontained by western ideological systems. It was not a long-lived phenomenon-French Maoism at Tel quel subsided by 1975-but it is noteworthy to the extent that it illustrates yet another field touched by the pervasive logic of the Orient as Other. At this particular moment the fascination with China was a means of figuring not only the feminist-psychoanalytic desires of Kristeva, and the semiotic-psychoanalytic desires of Barthes, but also the political desires of the intellectuals at Tel quel (including Kristeva and Barthes) as well.

\footnotetext{
${ }^{31}$ André Barjonet was an economist, and former head of the social research department of the CGT, who resigned in protest against the CGT's role in the strikes on May 25. In "C.G.T., 1968," Lestemps modernes, no. 265 (July 1968): 94-103. Barjonet objected to the authoritarianism of the communist leadership; he asserted that the leaders of both the CGT and the PCF dictated a narrow, undialectical sense of the relationship between "consciousness" and "social practice," and fought ceaselessly against the spontaneity of the masses, positions, he argued, that were fundamentally antimarxist.
} 
The journal Tel quel, founded in 1960, published essays in avantgarde literary criticism and semiotic theory. Its inclination toward a leftist politics developed, by 1966, into a deep interest, among certain members of its editorial committee, in the Chinese Cultural Revolution. In the summer of $1968 \mathrm{Tel}$ quel described the May events as "la Révolution ici maintenant" (the Revolution here now) and heralded May as a Parisian version of the Cultural Revolution. A Groupe d'études théoriques was set up, which met weekly to construct "une théorie tirée de la pratique textuelle" (a theory drawn from textual practice), declaring that "cette construction devra faire partie, selon son mode de production complexe de la théorie marxiste-léniniste, seule théorie révolutionnaire de notre temps, et porter sur l'intégration critique des pratiques les plus élaborés (philosophie, linguistique, sémiologie, psychanalyse, 'littérature,' histoire des sciences)" (this construction will have to form a part, in accordance with its complex mode of production, of Marxist-Leninist theory, the only revolutionary theory of our time, and work toward the critical integration of the most developed practices of philosophy, linguistics, semiology, psychoanalysis, "literature," and the history of science). ${ }^{32}$ Thus, the ambitious program of the telquelistes called for the elaboration of theories of "textual politics," that is, a politics inhering in writing practices and in the subject's relationship to language and signification. During this time $\mathrm{Tel}$ quel investigated those textual practices-in poetics, in cultural texts, in psychoanalysis-that radically subverted the subject's stable self-identification in language. The most powerful work developed by theorists at Tel quel was the argument for the materiality of language and literature, the consequences of which were that the economic was no longer considered the only realm of political change, and that linguistic and formal experiments in art and literature were considered to have the power to transform the very structures of bourgeois ideology that determined subjectivity. As early as the winter of 1970, Sollers had translated some of Mao's poems in the journal, but it was not until 1971 that China was hailed as the revolutionary Other, a site of revolutionary practice which those at Tel quel believed closely embodied the very "textual politics" they desired. By 1971 a manifesto indicating the journal's enthusiastic embrace of Maoism had been published; the political tenets of the Mouvement de juin 71 were

32Tel quel, no. 34 (Summer 1968): 4. 
consolidated, with the publication of a "Déclaration" and list of "Positions" appearing in Tel quel, no. 47 (Autumn 1971).

The declaration began with a protest against the censoring of MariaAntonietta Macciocchi's De la Chine at a commercial display by L'humanité, the Communist press. Tel quel editors viewed the suppression of this book about the Chinese Revolution and Chinese society to be one of the most revealing and dangerous choices of the PCF (referred to with lower-case letters as "pcf"). They argued that the choice to suppress De la Chine indicated a repressive and dogmatic policy, which colluded with and made possible the revisionist "line." Furthermore, they declared that revisionism-policies such as belief in the electoral process followed by the PCF and FGDS-was the primary instrument in support of bourgeois hegemony. In this sense the declaration of $\mathrm{Tel}$ quel's Maoism was specifically a reaction to the PCF's prohibitions; China was embraced as a privileged topos of revolution precisely because information about China was suppressed by L'humanité and the PCF: "La censure inévitable du révisionnisme sur la Chine est le prix à payer par lui pour que cette hégémonie soit totale. . . . On comprend donc comment, dans ces conditions, la révolution culturelle prolétarienne chinoise, plus grand événement historique de notre époque, dérange le calcul révisionniste et qu'il fera tout pour la falsifier. Eh bien, nous, nous ferons tout pour l'éclairer, l'analyser et la soutenir" (p. 134) (Revisionism's inevitable censuring of China is the price it pays so that this hegemony remains total. . . . We understand how, then, that under these conditions the Chinese Cultural Proletarian Revolution, the greatest historical event of our epoch, so disturbs the revisionist reasoning that they will do everything to falsify it. And so, for our part, we will do everything to illuminate it, to analyze it, and to support it). In 1971 the Maoist telquelistes described themselves less by means of new tenets or associations with the writings of Mao Zedong and more by distinguishing themselves from PCF positions and in terms of what was suppressed from the PCF line. In this sense the Tel quel Maoists did not identify Maoism as an agenda or a program of initiatives but rather identified with China as the suppressed Other of French communism.

The "Positions du Mouvement de juin 71," which followed the "Déclaration," included a list of distinctions between the Maoism of Tel quel and the older communism. In these positions the PCF line was 
characterized as a "ligne petit bourgeois," serving the bourgeoisie and revisionism, whereas Maoism was declared the "ligne révolutionnaire" (p. 136) directly serving the proletariat.

Le mouvement de juin 71 luttera à l'intérieur et à l'extérieur de Tel Quel pour développer . . . ses thèses. . . . Tel Quel doit être: un instrument de travail et d'analyse révolutionnaire, un instrument actif de la transformation actuelle de l'idéologie .. . [une revue qui réfléchit] la production du nouveau dans le procès d'avant-garde littéraire, philosophique, scientifique, politique. (p. 136)

[The June ' 71 movement will struggle on the inside and outside of $\mathrm{Tel}$ quel to develop its theses. . . . Tel quel must be: an instrument for work and revolutionary analysis, an active instrument in the current transformation of ideology ... (a review that reflects) the new production in the literary, philosophical, scientific, and political avant-gardes.]

The position statement began by characterizing Tel quel in a number of ways that implicitly criticized, or differentiated itself from, the PCF: the notions that its struggle would occur "à l'intérieur" and "à l'extérieur" of the theory-setting body of the journal, and that its primary field of action would be ideology. The location of struggle both inside and outside the journal implied a reaction against the closed body of the PCF leadership, and described a model of decision making that would be self-critical and would not exclude divergent opinions. In targeting the transformation of ideology as the primary field of activity, Tel quel joined its concerns with several other Marxist theories (those of Louis Althusser or others such as Macciocchi interested in Gramsci), which were concentrating less on action against the economic base per se (that is, changes in the economic mode of production) and more on the development of a critique of ideology, or theories of cultural intervention. In general, the emphasis on ideology reflected a desire to find a theory of cultural revolution in the largest sense, one that would call for a complete disruption of customs and ways of thinking, with the goal of eradicating from them vestiges of structures carried over from the past. For Tel quel this desire was a result of interpreting May 1968 as a failure, as the revolution's having been defeated by the overpowering body of administrative, pedagogical, and cultural superstructures. The position statement continued: 
"Le lecteur de Tel Quel" . . est en mesure de reconnaître, à l'intérieur et à l'extérieur de Tel Quel, deux lignes, deux voies, deux objectifs antagonistes. De l'issue de la lutte entre ces deux lignes dépend soit la victoire de l'avant-garde, soit sa défaite dans l'académisme, l'opportunisme, la répétition. Camarades! nous ne sommes pas en 1920 ou 1930, ni même en 1960, mais en 1971. Notre avant-garde n'est pas le formalisme, le futurisme, le surréalisme, le "nouveau nouveau roman," etc. mais la percée d'une production révolutionnaire aujourd'hui. Aujourd'hui, c'està-dire à l'époque qui a vu la révolution culturelle prolétarienne chinoise, Mai 1968 en France et, sur la scène internationale, le resurgissement, la propagation irréversible de la théorie et de la pratique révolutionnaire de notre temps: la pensée-maotsétoung. (p. 136)

["The reader of Tel quel" will recognize that, inside and outside Tel quel, there are two lines, two views, two antagonistic objectives. Out of the issue of the struggle between these two lines results either the victory of the avant-garde, or its defeat in academicism, opportunism, and repetition. Comrades! We're not in 1920 or 1930, not even in 1960, but in 1971. Our avant-garde is not formalism, futurism, surrealism, or a "new nouveau roman," but rather a breakthrough of revolutionary production for today. A today, that is, which has seen the Chinese Cultural Revolution, May 1968 in France, and, on the international scene, a resurgence and irreversible spread of the revolutionary theory and practice of our time: Maoism.]

In this passage a n even more emphatic opposition is drawn between a traditional line and Maoism as its critique. For Tel quel Maoism was not the theory of Mao Zedong as it functioned in the Chinese Cultural Revolution but rather an abstract notion of "le plus avant-garde et révolutionnaire" - an analogue of what was for Baudelaire, in his time, "le plus moderne" - the Other of established orthodoxy. The definition of "today" as a period that "has seen the Chinese Cultural Revolution, May 1968 in France" associates the Cultural Revolution with May 1968 as if they represented parallel, though perhaps unequal, events. In historical terms this parallel ignores many things, the least of which is mere scale: it is fair to say that more than a decade of immense upheaval in the social, economic, military, and bureaucratic areas of Chinese life, affecting hundreds of millions of people, can only with difficulty be glibly compared to one month of strikes in France. It is the very nonequivalence of these two events that underscores the logic of desire and substitution through which the imagined success of the Chinese Cultural Revolution is substituted for the 
judged failure of the events of May, which is essentially what the French Maoists were doing in turning to China after 1968.

It must be noted that in 1971, before their 1974 visit, the telquelistes knew very little about China. And because of this limited knowledge, both of these 1971 documents invoke repeatedly "la pensée maotsétoung" without reference to either the political leader Mao, his writings, or the People's Republic of China. Rather, "Maoism," conjured as French communism's Other, was a manner of signifying a revolutionary practice whose very political and geographic distance from the West rendered it more powerful because it could not be subsumed by western social systems or western explanations. Even more particularly, French intellectuals at Tel quel in 1971 were searching precisely for a nonoccidental "Marxist" theory and practice of cultural revolution, because they claimed that May 1968 foregrounded the danger that western Marxisms could themselves be co-opted by the capitalist system.

The lack of knowledge about China also enabled Tel quel's theorists to idealize the Cultural Revolution as the epitome of "permanent revolution," a revolution which they constituted as having successfully reintegrated into the factories and countrysides the solidifying elite strata of administrators, bureaucrats, and technicians. In addition, Tel quel elaborated on the then popular notion of the Chinese Cultural Revolution as a continuous critique of ideology, imagining that the Chinese Cultural Revolution also included a vigorous and continual critique of art and literature, resulting in an ever-changing and ultimate avant-garde. It is in this latter sense particularly that $\mathrm{Tel}$ quel romanticized China as a utopian aesthetic; because information about China was prohibited and censored, the theorists at Tel quel were able to situate their abstract notions of textual practice there without risk of contradiction or disillusionment.

Even in 1974, however, after Tel quel's group trip to China, which included Philippe Sollers, Marcelin Pleynet, and François Wahl, as well as Barthes and Kristeva, the utopianization of China continued. The China evoked in the issue "En Chine" (no. 59, Autumn 1974), did not represent the economic and political struggles throughout the People's Republic of the early 1970 as it recovered from, and reassessed the gains and losses of, the Cultural Revolution. Rather, Tel quel praised and objectified China as a type of revolutionary practice in the 
realm of the "poetic"; Tel quel projected China as the location of a unique textual politics and practice, and proposed that this textual activity was central to Chinese society in a manner entirely different from the place of art in western society. In this issue Sollers wrote about China's "dimension 'poétique'": "Ces poèmes ne sont pas un décoration, comme trop d'Occidentaux ont tendances à la penser. Ils ont une triple portée: émotive-historique, graphique, politique.... [Le lyrisme chinois est] un dynamisme du geste, de la transformation" (pp. 15-16) (These poems are not a decoration, as many Westerners have the tendency to think. They carry a triple function: historicalemotive, graphic, political. . . . [Chinese lyricism is] a dynamism of physical action, of transformation). Even after Tel quel's visit to the People's Republic, China is selectively idealized as "poesis"; more than that, Sollers suggests that the visit there revealed China to be the very embodiment of Tel quel's critical and aesthetic project. This fictionalizing of China as a poetic avant-garde occurs in Kristeva's Des chinoises (p. 16) as well, where she describes the Chinese revolutionary example as being visible through "le 'dada' de la politique," thus conflating China (and ignoring China's predominant socialist realism) with the proto-surrealism of the French dada movement. These final representations of China as a poetic avant-garde illustrate the degree to which Tel quel's embrace of Maoism was commensurate with the valorization of an Imaginary textual politics over any dimension of social politics in France. Even after Tel quel no longer advocated Maoism, those associated with the journal did not take up the social struggles of the French Left. French Maoism served initially as the vehicle for Tel quel to differentiate itself from traditional Marxism, but ultimately, the result was that Tel quel expanded its theories of textuality and retreated from activist social politics. 33

Indeed, when we consider the political context of this interest in China represented by Tel quel, Kristeva, and Barthes, it is evident that the embrace of Maoism and the fetishizing of China represent more than a projection of the Orient as Other by a group of leftist intellectuals disillusioned after May 1968. It also reveals their judgment that

\footnotetext{
${ }^{33}$ For a satiric commentary on the conservatism of former French Maoists, see Guy Hocquenghem, Lettre ouverte à ceux qui sont passés du col Mao au Rotary (Paris: Albin Michels, 1986).
} 
socialist revolution could never occur in France and therefore that nothing would be sacrificed if they withdrew their political focus from France and turned their gaze toward a political utopia elsewhere. In a sense it represented a desertion of the revolutionary possibilities and the continuing contradictions created by May 1968. The French romance with Maoism in the early 1970 served as an escape from the demanding struggles in France itself. In turning to China, these writers could ignore not only the continuing conflicts with a conservative regime, and the important work of forging dialogues among various old and new Left factions, but also a new situation of growing social inequality as immigrant populations from North Africa and Indochina settled in France, constituting a new class of workers in the French economy. The fetishizing of China was symptomatic of an allor-nothing absolutism, which readily substituted an imaginary Cultural Revolution elsewhere because it was thought that the revolution could not be achieved at home.

Although the May events did not bring about a revolutionary transformation of French society, they did imply that large-scale and farreaching popular movements are possible. The student and workers' strikes of 1968 addressed issues that extended beyond each group's individual demands; together for one month, the two popularly based movements had called the entire structure of society into question. The students' critique of the university became a broad critique of French society itself, a challenging of the consumer society, class privileges, and authoritarian structures, as well as a bold rejection of social regulation and determination. In addition to higher wages, the workers had called for self-management, demanding that they should be involved in decision making at the plant level, and that all information about operations should be spread throughout the work force; a view heard constantly among workers during the May uprising was that work is more than money and that human dignity is as valid a union demand as higher pay. After 1968 Gaullist state power was never the same; the 12 million no votes to a Gaullist referendum in April 1969 sent De Gaulle into retirement. The strikes brought many significant changes in the structure of the university and the factory. Most significant, the social movements of feminism, gay liberation, and self-determination emerged out of the events of 1968 . Not only did the turn toward an 
imaginary Maoism refuse to recognize the advances that were actually achieved at the time but, more important, it neglected the mandate that there was still work to be done.

\section{The (Post)colonial Gaze}

The social productions, historical frameworks of inscription, and cultural functions of these three postcolonial French representations of the "maternal," imaginary Orient differ greatly from Flaubert's nineteenth-century representations of "la femme orientale," KuchukHânem, discussed in Chapter 3. Nonetheless, these twentieth-century projections of China as a fiction of absolute cultural and sexual difference from the West are more similar to Flaubert's representation of the oriental woman than one might at first imagine; Kristeva's and Barthes's rhetorical postures particularly recall Flaubert's orientalism. Kristeva's description of her first encounter with the Chinese is reminiscent of Flaubert's Correspondance: she not only duplicates the structure of address which makes the oriental Other an object of exchange between occidental writer and receivers, but also she attributes to that otherness similar qualities of silence, inertia, and indifference:

Une foule immense est assise sous le soleil: elle nous attend sans mot, sans mouvement. Des yeux calmes, même pas curieux, mais légèrement amusés ou anxieux, en tout cas perçants, et sûrs d'appartenir à une communauté avec laquelle nous n'aurons jamais rien à voir. Ils ne fixent pas en nous l'homme ou la femme, le jeune ou le vieux, le blond ou le brun, tel trait du visage ou du corps. ${ }^{34}$

[An immense crowd is seated in the sun; it waits for us without a word, without moving. Calm eyes, not even curious, but slightly amused or anxious, in any case piercing, and certain of belonging to a community with which we will never have anything to do. They don't distinguish among us man or woman, young or old, blonde or brunette, this or that feature of face or body.]

The Chinese crowd is homogenized and distanced as Other to the group of French intellectuals traveling in China in 1974. They are still and silent, their collective gaze distant, impenetrable, yet piercing-

\footnotetext{
${ }^{34}$ Kristeva, Des chinoises, pp. 13-14.
} 
excluded and excluding-and of one blended character, as if the crowd were like a single mirror reflecting the travelers' "étrangeté." "Ils ne fixent pas en nous l'homme ou la femme, le jeune ou le vieux" resonates with Flaubert's assertion that the oriental woman "ne fait aucune différence entre un homme et un autre homme." In both situations the oriental is represented by the French writers as speechlessly Other, indiscriminate rather than distinguishing among observers. The undifferentiating gaze of the French text is attributed to the gaze of the (undifferentiated) Chinese; that is, the Chinese are represented as doing the very thing that the textual representation does to them. In both, the French readers are the audience who receive and, as addressees, participate in these representations. This early passage from Des chinoises strikes the keynote of the entire text, in which the Chinese, and ultimately Chinese women as inheritors of a matriarchal tradition and maternal culture, are homogenized as the absolute cultural and sexual Others of the occidental tradition.

In Barthes's piece Alors la Chine? as well no one person is ever engaged or described. China exists only as a vast landscape of faceless, indistinguishable people-"ce peuple immense" - who are of one homogeneous character: "Dans le pénombre calme des salons d'accueil, nos interlocuteurs (des ouvriers, des professeurs, des paysans) sont patients, appliqués (tout le monde prend des notes: nul ennui, un sentiment paisible de travail commun)" (In the calm half-light of the reception room, our interlocutors [workers, professors, peasants] are patient, conscientious [everyone takes notes, not a trace of boredom, rather a peaceful feeling of teamwork]). ${ }^{35}$ In Barthes's description, although the Chinese people speak and communicate ("nos interlocuteurs"), they are also evoked as indistinguishable and collective. The parenthetical gloss- "des ouvriers, des professeurs, des paysans"-suggests that there are no class divisions in the new China, that workers, professors, and peasants all do the same work in an identical manner. In less than three decades, this suggests, China has achieved an egalitarianism unparalleled-as well as impossible, the essay implies-in the western world. In other words, a tautological rhetoric is used in this evocation of China: the quality of homogeneity among the Chinese is asserted as the evidence that Chinese society is 
without class divisions. As in the earlier orientalist portraits, the notion of the oriental people as unvaried and indistinguishable recurs. Like many of the preceding orientalist texts, including Flaubert's Voyage en Orient, both Kristeva's and Barthes's texts are also travelogues; to the degree that both narratives about the People's Republic of China reiterate certain generic and rhetorical features of travel literature (the trope of arrival, as well as the requisite description of the foreign people as incomprehensible), they fall very much within the body of French orientalism.

The theoretical projects of Tel quel and the semioticians Barthes and Kristeva were concerned with criticizing the power of the French state and its ideology, an ideology that had justified, among other things, imperialist policies in North Africa and Indochina. In this sense the constructions of China in Tel quel, Des chinoises, and Alors la Chine? conjured the oriental Other not as a colonized space but as a desired position outside western politics, ideology, and signification. Yet a final irony remains: these postcolonial refigurations of China continued to figure the Orient as the Other, no longer as colonized but as utopian, and this romantic regard for China permitted intellectuals to disregard the situation of actual postcolonial peoples residing and laboring in France itself. By the 1950s French colonialism in Africa and Asia had been rigorously challenged by nationalist groups in Algeria, Tunisia, Morocco, and Indochina, as well as by leftist groups within France critical of French policy. Intensification of the anti-French nationalist movements in Morocco and Tunisia forced France to agree to the independence of these countries in the early 1950s. Defeats in both Indochina in 1954 and in the Algerian war of the late 1950s marked the decline of French imperial power, and in 1958 De Gaulle was forced to seek an end to the war in Algeria on the terms of the FLN (Front de liberation national), the Algerian nationalist organization. Algeria received its independence in 1962. Yet, despite the policies of French decolonization during the late 1960s, it is evident that the French involvement with Asia and the Third World continued into the 1970s, even though some of the more overt political apparatuses of colonialism had ended. In the postcolonial period the former colonial "gaze" toward Asia may have disappeared from official ideology, but it persists nonetheless, on the parts of both the political Right and Left. We need only consider the surprising credibility of Jean-Marie Le Pen and 
the Front national $(\mathrm{FN})$ to appreciate that even though French colonialism has ended in name in North Africa, the Caribbean, and Indochina, the displaced populations from these regions have not encountered vastly changed relations between "colonizer" and "colonized" in the French metropolis. From this discussion of Kristeva, Barthes, and Tel quel, we understand that even on the Left the orientalist gaze may reemerge, even when the purpose of its project is to criticize state power and social domination. In this regard, for activists and intellectuals of the contemporary Left the example of French Maoism suggests that the continuing utopian tendency of projecting revolutionary, cultural, or ethnic purity onto other sites, such as the Third World, must be scrutinized and challenged. For those critical articulations that successfully break with orientalism, that resist the logic of otherness, we must finally look away from the European context of orientalism to other locations on the discursive terrain, such as spaces of decolonization, subalternity, and feminism. ${ }^{36}$

${ }^{36}$ For a brief discussion of the dangers of essentializing the position of the "Third World woman," see my review of Trinh T. Minh-ha's Woman, Native, Other: Writing Postcoloniality and Feminism, Sub-Stance 62-63 (1991); 213-16. 